ANL/NDM--118

DE9 1006962

\title{
CHARACTERISTICS OF THE SAMPLES IN THE \\ FNG FISSION DEPOSIT COLLECTION
}

by

J. W. Meadows

December 1990

\author{
Engineering Physics Division \\ ARGONNE NATIONAL LABORATORY \\ 9700 South Cass Avenue \\ Argonne, Illinois 60439 \\ U.S.A.
}

\section{MASTER}




\section{NUCLEAR DATA AND MEASUREMENTS SERIES}

The Nuclear Data and Measurements Series presents results of studies in the field of microscopic nuclear data. The primary objective is the dissemination of information in the comprehensive form required for nuclear technology applications. This Series is devoted to: a) measured microscopic nuclear parameters, b) experimental techniques and facilities employed in measurements, c) the analysis, correlation and interpretation of nuclear data, and d) the evaluation of nuclear data. Contributions to this Series are reviewed to assure technical competence and, unless otherwise stated, the contents can be formally referenced. This Series does not supplant formal journal publication, but it does provide the more. extensive information required for technological applications (e.g., tabulated numerical data) in a timely manner. 


\section{TABLE OF CONTENTS}

\section{Page}

List of Additional Titles

in the ANL/NDM Series

V

vii

ABSTRACT

I. INTRODUCTION

II. SAMPLES

A. Deposit Preparation

B. Deposit Assay

C. Deposit Quality

III. THE LOW-GEOMETRY ALPHA COUNTER 3

IV. FISSION DEPOSIT CHARACTERISTICS

4

V. COMMENTS

REFERENCES

TABLES

FIGURES 


\title{
INFORMATION ABOUT OTHER ISSUES OF THE ANL/NDM SERIES
}

A list of titles and authors for all the previous issues appears in each report of the series. The list for reports ANL/NDM-1 through ANL/NDM-75 appears in ANL/NDM-76, and ANL/NDM-91 contains the list for reports ANL/NDM-76 through ANL/NDM-90. Below is the list for ANL/NDM-91 up to the current report. Requests for a complete list of titles or for copies of previous reports should be directed to:

\author{
Section Secretary \\ Applied Nuclear Physics Section \\ Engineering Physics Division \\ Building 316 \\ Argonne National Laboratory \\ 9700 South Cass Avenue \\ Argonne, Illinois 60439 \\ U.S.A.
}

ANL/NDM-91 A.B. Smith, P.T. Guenther and R.D. Lawson, On the Energy Dependence of the Optical Model of Neutron Scattering from Niobium, May 1985.

ANL/NDM-92 Donald L. Smith, Nuclear Data Uncertainties (Vol.-I): Basic Concepts of Probability, December 1988.

ANL/NDM-93 D.L. Smith, J.W. Meadows and M.M. Bretscher, Integral Cross-section Measurements for ${ }^{7} \mathrm{Li}\left(n, n^{\prime} t\right)^{4} \mathrm{He},{ }^{27} \mathrm{Al}(n, p)^{27} \mathrm{Mg}, \quad{ }^{27} \mathrm{Al}(n, \alpha)^{24} \mathrm{Na}$, ${ }^{58} \mathrm{Ni}(n, p)^{58} \mathrm{Co}$, and ${ }^{60} \mathrm{Ni}(n, p){ }^{60} \mathrm{Co}$ Relative to $238 \mathrm{U}$ Neutron Fission in the Thick-target ${ }^{9} \mathrm{Be}(d, n){ }^{10} \mathrm{~B}$ Spectrum at $E_{\mathrm{d}}=7 \mathrm{MeV}$, October 1985 .

ANL/NDM-94 A.B. Smith, D.L. Smith, P. Rousset, R.D. Lawson and R.J. Howerton, Evaluated Neutronic Data File for Yttrium, January 1986.

ANL/NDM-95 Donald L. Smith and James W. Meadows, A Facility for High-intensity Neutron Irradiations Using Thick-target Sources at the Argonne Fast-neutron Generator, May 1986.

ANL/NDM-96 M. Sugimoto, A.B. Smith and P.T. Guenther, Ratio of the Prompt-fission-neutron Spectrum of Plutonium-239 to that of Uranium-235, September 1986.

ANL/NDM-97 J.W. Meadows, The Fission Cross Sections of 230 Th, ${ }^{232}$ Th, $233 \mathrm{U}$, ${ }^{234} \mathrm{U}, 236 \mathrm{U},{ }^{238} \mathrm{U},{ }^{237} \mathrm{~Np},{ }^{239} \mathrm{Pu}$, and $242 \mathrm{Pu}$ Relative $235 \mathrm{U}$ at $14.74 \mathrm{MeV}$ Neutron Energy, December 1986 .

ANL/NDM-98 J.W. Meadows, The Fission Cross Section Ratios and Error Analysis for Ten Thorium, Uranium, Neptunium and Plutonium Isotopes at $14.74-\mathrm{MeV}$ Neutron Energy, March 1987.

ANL/NDM-99 Donald L. Smith, Some Comments on the Effects of Long-range Correlations in Covariance Matrices for Nuclear Data, March 1987.

ANL/NDM-100 A.B. Smith, P.T. Guenther and R.D. Lawson, The Energy Dependence of the Optical-model Potential for Fast-neutron Scattering from Bismuth, May 1987. 
ANL/NDM-101 A.B. Smith, P.T. Guenther, J.F. Whalen and R.D. Lawson, Cobalt: Fast Neutrons and Physical Models, July 1987.

ANL/NDM-102 D. L Smith, Investigation of the Influence of the Neutron Spectrum in Determinations of Integral Neutron Cross-Section Ratios, November 1987.

ANL/NDM-103 A.B. Smith, P.T. Guenther and B. Micklich, Spectrum of Neutrons Emitted From a Thick Beryllium Target Bombarded With 7 MeV Deuterons, January 1988.

ANL/NDM-104 L.P. Geraldo and D.L. Smith, Some Thoughts on Positive Definiteness in the Consideration of Nuclear Data Covariance Matrices, January 1988.

ANL/NDM-105 A.B. Smith, D.L. Smith, P.T. Guenther, J.W. Meadows, R.D. Lawson, R.J. Howerton, and T. Djemil, Neutronic Evaluated Nuclear-Data File for Vanadium, May 1988.

ANL/NDM-106 A.B. Smith, P.T. Guenther, and R.D. Lawson, Fast-Neutron Elastic Scattering from Elemental Vanadium, March 1988.

ANL/NDM-107 P. Guenther, R. Lawson, J. Meadows, M. Sugimoto, A. Smith, D. Smith, and R. Howerton, An Evaluated Neutronic Data File for Elemental Cobalt, August 1988.

ANL/NDM-108 M. Sugimoto, P.T. Guenther, J.E. Lynn, A.B. Smith, and J.F. Whalen, Some Comments on the Interaction of Fast-Neutrons with Beryllium, November 1988.

ANL/NDM-109 P.T. Guenther, R.D. Lawson, J.W. Meadows, A.B. Smith, D.L. Smith, and M. Sugimoto, An Evaluated Neutronic Data File for Bismuth, November 1989.

ANL/NDM-110 D.L. Smith and L.P. Geraldo, A Vector Model for Error Propagation, March 1989.

ANL/NDM-111 J.E. Lynn, Fifty Years of Nuclear Fission, June 1989.

ANL/NDM-112 S. Chiba, P.T. Guenther, and A.B. Smith, Some Remarks on the Neutron Elastic- and Inelastic-Scattering Cross Sections of Palladium, May 1989. June 1989

ANL/NDM-113 J.E. Lynn, Resonance Effect3 in Neutron Scattering Lengths,

ANL/NDM-114 A.B. Smith, R.D. Lawson, and P.T. Guenther, Ambiguities in the Elastic Scattering of $8 \mathrm{MeV}$ Neutrons from Adjacent Nuclei, October 1989.

ANL/NDM-115 A.B. Smith, S. Chiba, D.L. Smith, J.W. Meadows, P.T. Guenther, R.D. Lawson, and R.J. Howerton, Evaluated Veutronic File for Indium, January 1990.

ANL/NDM-116 S. Chiba, P.T. Guenther, R.D. Lawson, and A.B. Smith, Neutron Scattering from Elemental Indium, the Optical Model, and the Bound-State Potential, June 1990.

ANL/NDM-117 Donald L. Smith and Luiz P. Geraldo, An Evaluation of the Nb-93( $\left.n, n^{\prime}\right) N b-93 m$ Dosimeter Reaction for ENDF/B-VI, November 1990. 


\title{
CHARACTERISTICS OF THE SAMPLES \\ IN THE \\ FNG FISSION DEPOSIT COLLECTION.
}

\author{
J. W. Meadows
}

\begin{abstract}
Information concerning the samples in the Fast Neutron Generator (FNG) Group's fission deposit collection has been assembled. This includes the physical dimensions, isotopic analyses, half-lives, alpha emission rates, specific activities and deposit weights.
\end{abstract}




\section{INTRODUCTION}

Over the past twenty years a number of thin deposits of thorium, uranium, neptunium, and plutonium isotopes suitable for use in fission detectors have been prepared by the Fast Neutron Generator (FNG) Group or obtained from other laboratories. The purpose of this memorandum is to gather the available information concerning these samples into one place and to enable anyone who may need such samples to use them with confidence. They were prepared for a number of purposes, but most were originally designed for use in fission cross section ratio measurements. Sorne are uniform deposits with well-determined masses that are suitable for use as neutron flux standards. The quality of others is doubtful. Altogether there are 108 samples. The preparation of the sampies and their assay by low-geometry alpha counting is described in Secs. II. and III. The information for the individual deposits is given in tables in Section IV. This includes deposit dimensions, alpha emission rates, isotopic analyses and half-lives that were used to calculate specific activities and, finally, the deposit weights determined from this information. Section V. gives specific comments concerning individual samples and groups of samples and Sec. VI. discusses the sources of error.

\section{SAMPLES}

\section{A. Deposit Preparation.}

The oldest deposits in this collection are the ${ }^{238} \mathrm{U}$ and $235 \mathrm{U}$ samples that were prepared by the evaporation of $\mathrm{UF}_{4}$. The quality of these deposits was very good, but the method required relatively large amounts of material and was not very suitable when the amount available was small or when the specific activity was very high. For this reason, most of the samples were made by electrodeposition where the deposit efficiency was good, the unused material could be readily recovered, and the cleanup of the equipment was uncomplicated. Thorium and uranium samples were prepared by molecular plating from solutions of the nitrates in anhydrous acetone and isopropyl alcohol, respectively, following a procedure described by Parker et al.1 Neptunium and plutonium samples were prepared following a method described by Ko. ${ }^{2}$ The thickness of a single deposition was always $>100 \mu \mathrm{g} / \mathrm{cm}^{2}$. Thicker samples were made by depositing several layers. As a general practice, a rather large number of samples were made, and those that did not appear to be of uniform thickness and have good adherence to the backing were discarded.

\section{B. Deposit Assay.}

The assay of these samples is based on low-geometry alpha counting using the counter described in Sec. III. Specific activities are calculated using the half-lives in Table I and the isotopic analyses in Table II. The accuracy depends on the quality of this data. When this program was begun, the quality of the half-life data for the isotopes involved was poor. This situation has changed in the past decade, and an impressive body of data now exists for the longer-lived actinides (see Table I.). The methods of isotopic analyses have also improved but, even at the beginning of this program, they were capable of very good results providing the concentration was $>1 \%$. Also, the analyses reported in Table II are based on severai independent measurements. Some of those samples where the principal alpha emitter is also the principal isotope are an exception to the rule. Nlthough these may be based on a single analysis, the high concentration yields a small error.

These samples may also include some shorter-lived isotopes of the element and the. lower members of the various decay chains. Fortunately, those isotopes with short half-lives have correspondingly high alpha energies and can be eliminated by energy 
discrimination. If a long-lived isotope is in the decay chain, it usually takes many years before its concentration becomes large enough for an appreciable correction. There are some intermediate cases, and each must be examined individually. For example, 2330 decays to ${ }^{229} \mathrm{Th}$ which has alpha decay energies near those of the parent isotope. The. correction approaches $0.1 \%$ after only 11 years.

\section{Deposit Quality.}

A judgment of the deposit quality is given in Table II for many of the deposits. The quality scale is excellent, very good, good, fair, poor, and very poor. It may be noted that there are no deposits in this collection that are judged to be excellent; neither are there any that are judged to be very poor. Excellent deposits do exist. They are usually prepared by evaporation onto very smooth backings. The evaporated deposits in this collection are judged to be no better than very good because the backings are not as smooth as they should be. All the deposits judged to be very poor, and many that were only poor, have been discarded.

The judgment of quality is based primarily on the deposit's appearance, but it is also influenced by the alpha and fission spectra. Under low magnification (10X or 20X) the ideal deposit appears to be a smooth, uniform layer on a smooth backing with no sign of granularity or clumping. The spectrum of a single alpha line is symmetric, rising rapidly for three or more orders of magnitude, then falling at the same rate. For thick deposits, the line will be broad but still symmetric, and will have a flat top. Poor deposits will show a decided tail on the low energy side. For fission spectra, the regior between the alphas and the fission fragments begins to fill in as the deposit thickens. It has been found empirically that the correction for fission events lost in the alpha region (extrapolation correction or $\mathrm{C}_{\mathrm{x}}$ ) is about the same as the correction for those fissions that are not counted because neither fragment escapes fror the deposit. ${ }^{9}$ For good deposits, the greatest part of this correction is

$$
\mathrm{L}=\mathrm{t} / 2 \mathrm{R}
$$

where $t$ is the deposit weight divided by the total area, and $R$ is the range of the average fission fragment (see Table IV.). Because of clumping, the effective value of $t$ may be much greater, with a corresponding increase in the effective value of $\mathrm{L}$ and also of $\mathrm{C}_{\mathrm{x}}$.

Figures 1 thru 6 illustrate alpha spectra for several of the deposits. The spectrum of the $235 \mathrm{U}$ deposit $25 \mathrm{~S}-5-3$ is shown in Fig. 1 . This is a very good deposit, prepared by NIST. Although it is fairly thick $\left(181 \mu \mathrm{g} \mathrm{U} / \mathrm{cm}^{2}\right)$, the alpha peaks are very clean and symmetric. Figures 2 and 3 show the spectra of two samples prepared by evaporation, U-235 SST-1 and U-235 SST-8. These are also rated very good, and their thickness is 132 and $200 \mu \mathrm{g} \mathrm{U} / \mathrm{cm}^{2}$, respectively. However, the quality of the backing is not as good as it should be, and the alpha spectra show a little more of a tail. The spectrum of $\mathrm{U}-238-213$ is shown in Fig 4. Its thickness is only $118 \mu \mathrm{g} . \mathrm{U} / \mathrm{cm}^{2}$, but its quality is poor. The ${ }^{234} \mathrm{U}$ alpha peak is broad and shows a decided low energy tail. Figure 5 shows the. spectrum of U-238-60. This is a rather thick deposit $\left(386 \mu \mathrm{g} \mathrm{U} / \mathrm{cm}^{2}\right)$, with a quality rating of good. It is made from very pure ${ }^{238} \mathrm{U}$, so its principal activity is $238 \mathrm{U}$. The alpha peak is broad due to the thickness of the deposit, but the spectrum is clean and shows only a small degree of tailing. Figure 6 shows the spectrum of $\mathrm{Pu}-239-267$. 'The aveiage. thickness of this sample is only $26 \mu \mathrm{g} . \mathrm{Pu} / \mathrm{cm}^{2}$, but it is rated as poor because of its appearance and the behavior of the fission spectrum. The alpha spectrum is fairly good although it does show some tailing. Figure 7 shows a typical alpha counter background. 
Figure 7 illustrates the correlation of $\mathrm{C}_{\mathbf{x}}$ with $\mathrm{L}$. In order to maintain clarity only a few data points are shown, but a more extensive survey is given in Fig. 7 of Ref. 9. With the exception of the deposits judged to be of poor quality (points labeled 239-267 and $238-213$ ), all the deposits referred to are rated as good or very good. All these points cluster around the line $C_{x}=L$ and the agreement can be considered fairly good. This is particularly true when it is remembered that $C_{\mathbf{x}}$ is a rather imprecise quantity whose size depends on just where the bias level was set. Furthermore, the information in Fig. 7 of Ref. 9 was taken from a number of measurements that were made for other purposes and whore there was no attempt to maintain a consistent bias setting. The poor deposits lie far abo re the line, as expected.

\section{THE LOW-GEOMETRY ALPHA COUNTER}

All alpha counting was carried out in a low-geometry counter constructed at ANL. The interior of the counter is shown schematically in Fig. 8. Critical tolerances were $\pm 0.00025 \mathrm{~cm}$. A silicon detector is positioned behind a $1.270 \mathrm{~cm}$ dia. aperture. The sample mounting depends on the particular sample, and Fig. 1 illustrates the mount for a. $2.54 \mathrm{~cm}$ dia. deposit on a $6.985 \mathrm{~cm}$ dia. fission chamber electrode. There are 5 possible sample positions at increments of $5.0800 \mathrm{~cm}$. At position 2, the distance from the top of the mounting block to the aperture plate is $9.6652 \mathrm{~cm}$. This distance was re-measured whenever the counter was reassembled after it was taken apart for cleaning. The total uncertainty in the sample position from all causes, including the failure of the deposit backing to lie flat against the mounting block, is about $0.0025 \mathrm{~cm}$.

Several small computer programs have been written to calculate the geometry factor under a variety of conditions. However, the following series approximation ${ }^{5}$ is adequate for most cases, providing that the sample and aperture are perpendicular to a common axis, the sample and aperture radii are $<<$ the separation distance, and the sample distribution is uniform.

$$
\begin{aligned}
\mathrm{G}=0.5\{1 & -\left[1 /(1+\beta)^{V^{2}}\right]-(3 / 8)\left[\beta \gamma /(1+\beta)^{5 / 2}\right]+(5 / 16)\left[\beta \gamma^{2} /(1+\beta)^{7 / 2}\right] \\
& -(35 / 64)\left[\beta^{2} \gamma /\left[(1+\beta)^{9 / 2}\right]-(35 / 128) /\left[\beta \gamma^{3} /(1+\beta)^{9 / 2}\right]\right. \\
& \left.+(315 / 256)\left[\beta^{2} \gamma^{3} /(1+\beta)^{1 / 2}\right]-(1155 / 1024)\left[\beta^{3} \gamma^{3} /(1+\beta)^{13 / 2}\right]\right\} \\
\beta= & \left(\mathrm{r}_{\mathrm{a}} / \mathrm{D}\right)^{2} \\
\gamma= & \left(\mathrm{r}_{\mathrm{s}} / \mathrm{D}\right)^{2} \\
\mathrm{r}_{\mathrm{a}}= & \text { aperture radius } \\
\mathrm{r}_{\mathrm{s}}= & \text { sample radius } \\
\mathrm{D} & =\text { sample-aperture separation distance }
\end{aligned}
$$

A point of caution if a different aperture is installed: The aperture should come down to a knife edge. The thickness "a" of the edge (see Fig. 9) will affect the geometry factor. For that part of the sample with $r<r_{a}$, the distance $D$ is actually $D+a$. For $r>r_{a}$, the sample-aperture distance is a combination of $D$ and $D+a$. This effect can be significant, particularly at position 1 . The edge thickness for the present aperture is quite small and the effect is negligible. However, some of the counting was cone using an aperture with an edge thickness of $0.020 \mathrm{~cm}$ and that is enough to have a detectable effect on the geometry factor of a $2.54 \mathrm{~cm}$ dia. deposit. A computer program was written to calculate the geometry factor, including this effect. When this correction is made, the counts made at position 1 , at the more distant positions and with other apertures agree within the statistical error. 


\section{FISSION DEPOSIT CHAR $\beta_{\Lambda}$ CTERISTİCS}

The physical characteristics of the deposits and the information on which the weight determination are based are given in Tables I thru V.

Table I lists the alpha and spontaneous fission half-lives of the sample isotopes. Table Il gives the physical characteristics of the samples. This includes the material, diameter and thickness of the backing; the diameter and estimated chemical composition of the deposit; and a subjective estimate of the quality of the deposit. Table III gives the isotopic analyses and the specific activities. The average fission fragment range for the deposit material is also included in this table. The specific activities are calculated using the half-lives given in Table I and the isotopic analyses in Table II. The uncertaintics in the half-lives are small, as are the uncertainties in most of the isotopic analyses, so most of the specific activities have small errors.

I able IV gives the alpha emission rate and its error, based on the most recent lowgeometry alpha count. The specific activities are repeated in Table IV for convenience, and the number of sample atoms and sample weights are calculated. It should be, remembered that thes ${ }^{n}$ samples were made for a variety of purposes, and for some of these. purposes an accurate mass determination based on an alpha count was not important. For some samples there is no isotopic analysis or, if there is one, it is not sufficiently accurate: to give a good specific activity. A few of the samples have never been alpha counted. $\Lambda$ few of the sample weights are based on comparative fission rates or on direct weighing. These are identified in the table. Table $\mathrm{V}$ gives a list of the correlated and partially correlated errors in the sample weights, based on alpha counting. This information is given regardless of how the weight information in Table IV was obtained, and you may notice that the total error is occasionally large. All the errors have been simplified to some? extent. For exarnple, the exror due to the nonuniformity of the sample and to deviations from the nominal diameter depends on the reciprocal of the sainple-detector distance. In estimating the errors, it was assimed that all the samples in a particular group were always counted at the same position - low activity samples at position 1; medium activity samples at position 2; high activity samples at position 3 . The last column of Table $\mathrm{V}$ shows the total nonrandom error for a given group of samples. This is the minimum error in the sample weight, based on alpha-counting. In most cases the error is only $\gtrsim$ few tenths of a percent but, in a few cases where the isotopic analyses is uncertain or where the weights are based on direct weighing, the error is as large as 5 or $10 \%$.

\section{COMMENTS}

$$
\text { Th-230 }
$$

\section{Th-230-49 thru Th-230-59 ( 5 samples)}

These samples are made from material that is $>99 \% 230 \mathrm{Th}$. At the time when these samples were made, the half-life of $230 \mathrm{Th}$ was very uncertain, so a measurement of the specific activity of this material using low-geometry alpha counting and mass determination by isotopic dilution established the half-life as $75380 \pm 300$ years. ${ }^{3}$ 'T'able V shows that the mass of these samples can be determined by alpha-counting to an accuracy of $<0.5 \%$. 
There are several groups of these deposits. The mass of one group can be measured accurately by alpha-counting. The others cannot.

Th-232-8 thru Th-232-21 (5 samples)

These are made from natural thorium spiked with ${ }^{230}$ Th to a concentration of about $0.4 \%$. There is no isotopic analysis. If one of the samples was sacrificed for isotopic analysis, the rest could be used as thorium standards.

\section{Th-232-30 thru Th-232-34 (3 samples)}

These were part of a group of samples used in the measurement of the $\mathrm{Th}-232 / \mathrm{U}-235$ fission cross section ratio and of the ${ }^{230} \mathrm{Th}$ half-life. The $\mathrm{Th}-230$ content is well established $(0.3830 \pm 0.0012 \%)$.

\section{Th-232-57 thru Th-232-63 (4 samples)}

These natural thorium samples were made for a special purpose. The low specific activity and the presence of other members of the decay chain in nonequilibrium amounts made both low-geometry and $2 \pi$ alpha counting impractical. Approximate weights were determined by direct weighing, but the uncertainty is large.

\section{Th-232-60 thru Th-232-61 (2 samples)}

These samples were made from natural thorium containing about $0.25 \% 235 \mathrm{U}$. The $235 \mathrm{U}$ was added so the energy response of a fission detector could be calibrated using $235 \mathrm{U}$ thermal fission.

\section{U-233}

\section{U-233-1002 thru U-233-12 (6 samples)}

These samples have two different sizes and backings, but they were all made from the same material (see Table III). The small amount of $232 \mathrm{U}$ does not contribute to the effective alpha-emission rate. Most of tha alphas emitted by ${ }^{232} \mathrm{U}$ and its daughters have energies well above the $233 \mathrm{U}$ alphas and can be rejected by energy discrimination. However, the first daughter of ${ }^{23} 3 \mathrm{U},{ }^{229} \mathrm{~T} h$, is just beginning to be significant in these samples. The correction is about $0.15 \%$.

$$
\mathrm{U}-234
$$

\section{U-234-1 thru U-234-48 (8 samples)}

These samples are made from three different batches of material. One was spiked with $9.9 \% 235 \mathrm{U}$. Almost all the alpha activity is due to $234 \mathrm{U}$, and Table $\mathrm{V}$ gives a minimum error in the mass determination of $0.2 \%$.

\section{$\mathrm{U}-235$}

There are several groups of $235 \mathrm{U}$ deposits. The one containing sample nos. $5-2$ thru R5 is made from material whose isotopic composition is particularly well determined. 


\section{U-235 SST-1 thru U-235 SST-8 (3 samples)}

These deposits were prepared by vacuum evaporation of $\mathrm{UF}_{4}$, so their uniformity should be very good. The backing material is steel, and some corrosion can be seen. These samples were made in the late 1960's, and their alpha activities have been measured at frequent intervals. In spite of corrosion spots appearing in the deposit area, no change has been observed in the alpha-emission rate. The isotopic analysis in Table II is based on an average of four measurements. The individual results are

Isotopic Analysis in Mole \%

\begin{tabular}{lrrrrr} 
Isotope & \multicolumn{1}{c}{$(1)$} & \multicolumn{1}{c}{$(2)$} & \multicolumn{1}{c}{$(3)$} & \multicolumn{1}{c}{$(4)$} & Average \\
& & & & & \\
$234 \mathrm{U}$ & 0.8548 & 0.8560 & 0.8561 & 0.8429 & 0.8524 \\
$235 \mathrm{U}$ & 93.2559 & 93.2267 & 93.2498 & 93.4037 & 93.2480 \\
$236 \mathrm{U}$ & 0.3317 & 0.3326 & 0.3321 & 0.3174 & 0.3284 \\
$238 \mathrm{U}$ & 5.5576 & 5.5847 & 5.5620 & 5.4360 & 5.5351
\end{tabular}

The errors reported with the isotopic analyses were internal precisions and were quite small. However, the scatter in the above table indicates an error of $>0.4 \%$ in the $234 \mathrm{U}$ content which is the critical number for the alpha emission rate. Sample mass comparisons reported in Ref. 6 placed the mass of SST -5 at $417.3 \pm 0.7 \mu \mathrm{g}$. This can be compared with the $416.3 \pm 2.0 \mu \mathrm{g}$ reported in Tables IV and V.

\section{U-235 5-2 thru R5 (9 samples)}

The material used for these deposits has been around since 1971 (e.g., W. P. Poenitz and R. J. Armani ${ }^{7}$, and three of the deposits included in this list were used in the 1984 ${ }^{235 \mathrm{U}}$ and ${ }^{239} \mathrm{Pu}$ sample mass comparison (see Ref. 6). A very accurate redetermination of the isotopic composition was reported by Poenitz et al., ${ }^{8}$ and these are the values given in Table III. The alpha activity of samples of this material was measured by low-geometry counting and their mass was obtained by isotopic dilution. The resulting specific activity was $2.437 \pm .0045 \alpha / \mathrm{s} / \mu \mathrm{g}$. 'The value listed in Table III is $2.436 \pm .010 \alpha / \mathrm{s} / \mu \mathrm{g}$, in very good agreement. The error is larger, as my estimate of the alpha-counting errors is somewhat. more conservative.

The chemical form of sample number $5-2$ is uncertain. It is believed to be some hydrated oxide and $\mathrm{UO}_{4} \cdot \mathrm{H}_{2} \mathrm{O}$ is assumed. This is just a guess based on the appearance of the deposit. Deposits 5-3 thru 6-7 are on platinum and were heated to nver $800{ }^{\circ} \mathrm{C}$ to convert the deposit to $\mathrm{U}_{3} \mathrm{O}_{8}$. Deposits $\mathrm{N}-\mathrm{U} 5-2, \mathrm{~N}-\mathrm{U} 5-3$, and R5 should be similar to $5-2$.

\section{$25 \mathrm{~S}-5-3$ (1 sample)}

This is a standard $235 \mathrm{U}$ deposit from NBS (now NIST) which was used in the 1984 ${ }^{235} \mathrm{U}$ sample mass intercomparison (see Ref. 6).

\section{$\underline{U}-235-0$ thru $U-235-14$ (3 samples)}

These samples were prepared about 1975. They contain about $5 \%{ }^{23} \mathrm{U}$, so the isotopic composition and the resulting mass determinations should be fairly accurate (see Table V). U-235-14 has been used frequently in fission cross section ratio measurement with consistent results. 


\section{U-235-1 thru U-235-3 (3 samples)}

These are fairly pure samples $(99.56 \% \mathrm{U}-235)$ that were used with the U-238 8-1 thru 8-3 samples in ratio measurements. An actual mass determination was never necessary and these samples have never been counted. In any case, the $234 \mathrm{U}$ content is not known well enough to give an accurate estimate of the specific activity.

\section{Ij-235-J thru U-235-T (4 samples).}

These thick, iarge--diameter deposits were prepared from $93 \% \mathrm{U}-235$ and have been converted to $\mathrm{U}_{3} \mathrm{O}_{8}$. The $234 \mathrm{U}$ conten $\imath$ is not well-enough known to get an accurate weight by alpha counting. The weights reported in Table IV were obtained by direct weighing and the accuracy is no better than 5 to $10 \%$.

\section{$\mathrm{U}-\mathbf{2 3 6}$}

\section{U-236-1 thru U-236-47 (11 samples)}

These deposits were prepared about 1975, and the comments for the ${ }^{234} \mathrm{U}$ deposits apply here alsc. There is no analyses for $\mathrm{U}-236-34$.

$$
\mathrm{U}-238
$$

\section{U-238-59 thru U-238-60 (2 samples)}

These two very thick deposits were prepared by the electrodeposition of very pure ${ }^{238} \mathrm{U}$. They were then heated to a fairly low temperature so the chemical form is that of a hydrated oxide. The composition $\mathrm{UO}_{4} \cdot \mathrm{H}_{2} \mathrm{O}$ is assumed. According to Table III, the material contains $<6 \mathrm{ppm}$ other isotopes. The alpha spectrum shows a group at the ${ }^{234} \mathrm{U}$ alpha energies that is consistent with about $6 \mathrm{ppm}: 234 \mathrm{U}$. Most of the ${ }^{234} \mathrm{U}$ alphas (if any) would be in the same region. However, they would not be detectable at the 6 ppm level due to the longer half-life.

Table $\mathrm{V}$ shows that the specific activity of these samples can be estimated with reasonable accuracy. However, they are not very suitable for highly accurate work because

(1) The low specific activity requires that they be counted at position 1 in the low-geometry alpha counter where the errors in the geometry factor are greatest (about $0.6 \%$ ). A very long count at position 2 in the low-geometry counter might bring the error down to $0.3-0.4 \%$.

(2) These are very thick samples, so corrections to the fission counts for loss in the deposit and for extrapolation to zero bias are large.

\section{U-238-211 thru U-238-217 (6 samples)}

These deposits have been spiked with about $1 \% 234 \mathrm{U}$ and about $2 \% 235 \mathrm{U}$. Two measurements of the isotopic abundances were made in 1971 . The agreement between the two suggests that the error in the ${ }^{234} \mathrm{U}$ content is no better than $0.4 \%$. The error in the weight, as determined by alpha counting, can be no better than about $0.5 \%$. This is good enough for these samples to serve as a secondary standard. The deposits were prepared about 1984 


\section{U-238- - thru U-238-9 (6 samples)}

These samples have been spiked with 3 to $10 \%$ 233U. There are two analyses for the $3 \%$ and $5 \%$ spikes that are in guod agreement, but only one for the $10 \%$ spike. In all cases the concentration of $233 \mathrm{U}$ is high enough so that the $\mathrm{U}-233 / \mathrm{U}-238$ ratio should be quite accurate. For the most part, these are thin, nongranular deposits. Unfortunately, the uniformity of some is not of the best. They can be counted at position 3 and greater, so the effect of any nonuniformity on the weight determination will not be large. In measurements where the neutron fluence is uniform across the deposit they can provide accurate results. The samples were deposited about 1975 .

\section{$\underline{U}-238-26$ (1 sainple)}

This sarıple was prepared from depleted uranium by vacuum evaporation of $\mathrm{UF}_{4}$. The concentration of $234 \mathrm{U}$ is not particularly accurate and it provides about $2.6 \%$ of the total alpha decay. Furthermore, the total alpha activity is too low for convenient counting. The weight quoted in Table IV is based on comparative fission rates. The accuracy is probably no better than $2 \%$.

\section{U-238-K thru U-238-O (4 samples)}

These thick, large-diameter, natural uranium deposits have been converted to $\mathrm{U}_{3} \mathrm{O}_{8}$. The weights given in Table IV are based on direct weighing and are probably no better than 5-10\%. The specific activities given in Table III are based on the isotopic: composition of natural uranium given in the General Electric Nuclide Chart. 'The deposits were prepared about 1980.

\section{U-238 8-1 thru U-238 8-3 (3 samples)}

These deposits were prepared about 1971. They contain $10 \% 233 \mathrm{U}$ and were used in the measurements of the $\mathrm{J}-238 / \mathrm{U}-235$ fission cross section ratio. Since the ratio of the masses was determined by the ratio of the thermal fission rates, it was never necessary to obtain an actual sample weight. For this reason, these samples have never been counted. The specific activity is adequate but the ${ }^{234} \mathrm{U}$ content, which contributes about 95 of the total alpha activity, has an error of nearly $5 \%$.

$$
\mathrm{Np}-237
$$

\section{Np-237-56 thru Np-237-80 (12 samples)}

These deposits range from about $12.8 \mu \mathrm{g} / \mathrm{cm}^{2}$ to $350 \mu \mathrm{g} / \mathrm{cm}^{2}$. They were made in 1981 from fairly clean material, and their quality ranges from poor to good. There is a trace of $240 \mathrm{Pu}$ but it contributes $<1 \%$ of the total activity and is well separated from the $237 \mathrm{~N} p$ alphas. In terms of atom $\%$, the $240 \mathrm{Pu}$ content is $<0.01 \%$. The limiting factor in

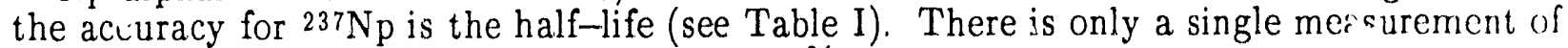
good precision, and its uncertainty is about $0.5 \%$.

$$
\mathrm{Pu}-239
$$

\section{$\underline{\mathrm{Pu}-239-12 \text { thru } \mathrm{Pu}} 239-14$ (3 samples)}

This material contains about $1 \% 240 \mathrm{Pu}$ which contributes about $3.6 \%$ of the alpha activity. The $24 \mathrm{Pu}$. does not contribute significantly, first, because it decays almost entirely by beta emission; second, because the analysis in 'Table 111 dates from about 19 ; 1 


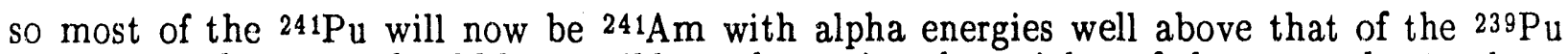
alphas. With care it should be possible to determine the weights of these samples to about $0.2 \%$.

\section{Fu-239-146 thru $\mathrm{Pu}-239-267$ (2 samples)}

'These two deposits were made from very pure ${ }^{239 \mathrm{Pu}} \mathrm{u}$, but the quality of the deposits is not all that good. On the basis of the size of the extrapolation correction to their fission spectra, I would characterize them as poor. That correction is nearly three times as large as it should be. The weight determinations by alpha counting should be quite accurate (about $0.2 \%$ ), but the uncertainties in the fission corrections may limit the overall accuracy (see Ref. 9).

\section{I-1-3 (1 sample)}

This is a standard deposit from NIST (formerly NBS). It was used in the $1984235 \mathrm{U}$ and ${ }^{239} \mathrm{Pu}$ sample mass intercomparison. ${ }^{6}$

$$
\mathrm{Pu}-242
$$

$\underline{\text { Pu-242-49 (1 sample) }}$

This is the only remaining ${ }^{242} \mathrm{Pu}$ deposit and it contains $9.1 \% 239 \mathrm{Pu}$. The small amc unt of $241 \mathrm{Pu}$ does not affect the alpha decay rate in any significant way (see $\mathrm{Pu}-239-12)$. The ${ }^{238} \mathrm{Pu}$ alphas can be rejected by energy discrimination.

\section{SOURCES OF ERROR}

The principal sources of error other than counting statistics are summarized in Table V. The following discussion gives the reasons behind the numbers.

\section{A. Counting Statistics}

This is a completely uncorrelated error. Table IV gives the alpha emission rates for most samples based on the most recent set of counts and the statistical error for those counts. New emission rates should be measured before any of these samples are used for any serious purpose.

\section{B. Error in the Half-Lives}

The decay rate for most samples is dominated by a single isotope, and only the error in that half-life (Table I0) need be considered. Two isotopes are necessary in only a few cases. This error is fully correlated for those samples where the same isotope dominates the alpha emission.

\section{Error in the Isotopic Analysis}

This source of error becomes important when the concentration of the isotope that dominates the alpha emission is low. Typical uncertainties in the minor isotopes is about 0.004 so if th? concentration is around $5 \%$ the error becomes negligible. The material used to make the $235 \mathrm{U}$ samples $5-2$ thru R5 is a special case. The uncertainty here is estimated to $<0.002 \%$. 


\section{Error in the alpha count due to sample characteristics}

These errors are fully correlated for all measurements made with a particular sample. They are otherwise uncorrelated.

\section{1. $\quad$ Sample Uniformity}

Many samples that appear to be uniform may actually have a thickness that deponds on the radius. This will affect the geometry factor, The effect depends on the rad: us and is inversely dependent on the sample--detector distance.

\section{2. $\quad$ Sample radius}

The geometry factor depends inversely on the sample radius. It is assumed that the uncertainty igt the radius is $\pm 0.051 \mathrm{~cm}$. For a $2.54 \mathrm{~cm}$ diameter sample this translates into a $0.43 \%$ uncertainty at position 1 . At position 3 it is negligible.

\section{3. $\quad$ Sample-Detector distance}

There may be some uncertainty in this distance due to bowing or other distortion of the sample backing. It is assumed that this is $\pm 0.2 \%$ at position 1 and is smaller at other positions.

\section{E. Errors in the Alpha Counter Dimensions}

These have nothing to do with the samples and are fully correlated for all measurements.

\section{1. $\quad$ Aperture radius} in the alpha count.

This is assumed to be $\pm 0.0005 \mathrm{~cm}$ which translates into a $0.1 \%$ uncertainty

\section{Shelf position}

It is assumed that this uncertainty introduces an error of $0.1 \%$ at position 1 . Since it is inversely proportional to the square of the sample aperture distance, it will be negligible at the other positions.

\section{ACKNOWLEDGMENTS}

This work was supported by the U.S. Department of energy under Contract No. W-31-109-Emg-38. The $234 \mathrm{U}$ and $236 \mathrm{U}$ deposits were prepared by G. H. Kucera. The author particularly wishes to thank R. J. Armani who proviced much useful advice and assistance and who prepared the $\mathrm{Pu}$ deposits and some of the $\mathrm{u}$ anium deposits. 


\section{REFERENCES}

1. W. Parker, H. Bildstein and N. Getoff, Nucl Instr. Methods $\underline{26}, 55$ (1964).

2. R. Ko, Electrodeposition of the Actinide Elements, HW-r1025, Hanford Atomics Products Report (1956).

3. J. W. Meadows, R. J. Armani, E. L. Calles and A. M. Essling, Phys. Rev. C22, $750(1980)$.

4. A. Lorenz, editor, Proposed Recommended List of Trans-Actinide Isotore Decay Data, Part I: Half-Lives, INDC(nds)-108/N, IAEA Nuclear Data Section (1979).

5. Benjamin P. Burtt, Nucleonics $\underline{5}, 28$ (August 1949).

6. W. P. Poenitz and J. W. Meadows, ${ }^{235} \mathrm{U}$ and ${ }^{230} \mathrm{Pu}$ Sample-Mass Determinations and Intercomparisons, ANL/NDM-84 (1983).

7. W. P. Poenitz and R. J. Armani, Nucl Energy 26, 483 (1972).

8. W. P. Poenitz, D. W. Maddeson, J. M. Gasidler, S. G. Carpenter and R. J. Armani, ${ }^{235} U(n, f),{ }^{238} U(n, \gamma),{ }^{238} U(n, f)$ and ${ }^{239} P u(n, f)$ Reaction Calibration at ZPPR, ANL-87-5 (1987).

9. J. W. Meadows, The Fission Cross Sections of $230 T h, 232 T h, 233 U, 234 U, 235 U, 236 U$, ${ }^{238} \mathrm{U},{ }^{237} \mathrm{~Np},{ }^{239} \mathrm{Pu}$ and $242 \mathrm{Pu}$ Relative to ${ }^{235} \mathrm{U}$ at $14.75 \mathrm{MeV}$ Neutron Energy, ANL/NDM-97 (1986).

10. C. Michael Lederer and Virginia S. Shirley, eds., Table if Isotopes, 7 h Edition, John Wiley \& Sons, New York (1978). 
Table I. The Alpha and Spontaneous Fission Half-Lives. ${ }^{a}$

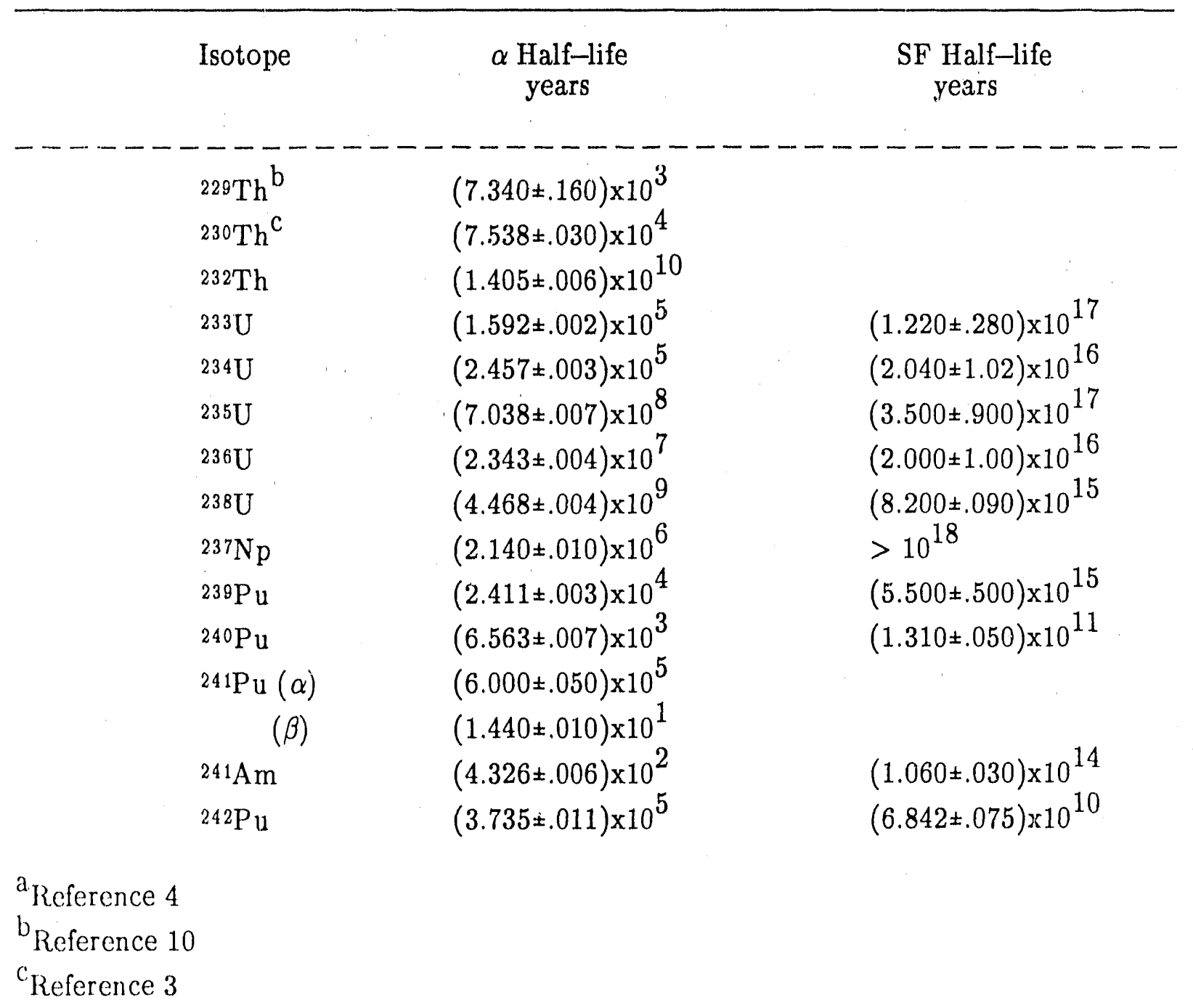


Table II. Description of samples.

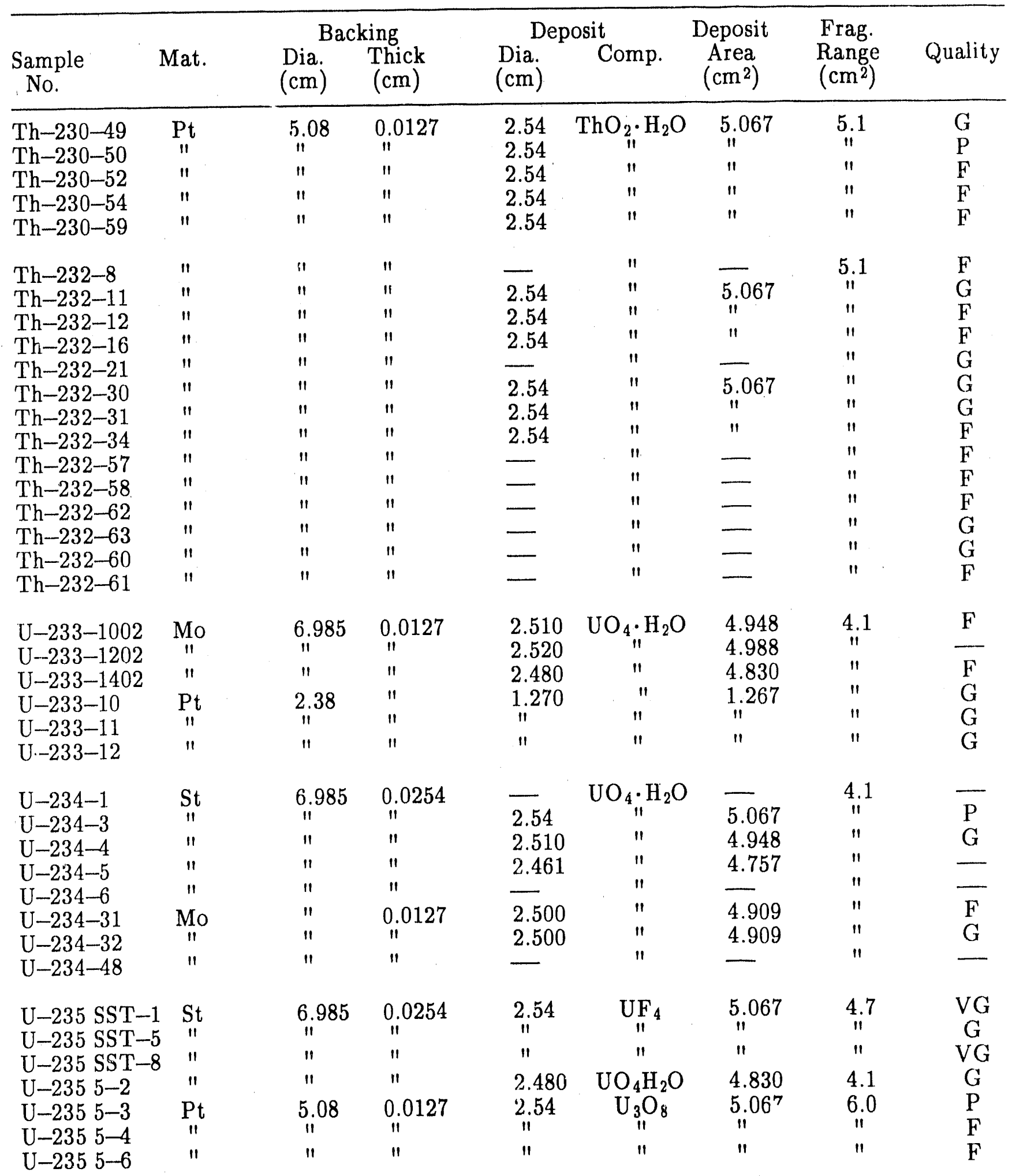


Table II. (continued)

\begin{tabular}{|c|c|c|c|c|c|c|c|c|}
\hline \multirow[b]{2}{*}{$\begin{array}{c}\text { Sample } \\
\text { No. }\end{array}$} & \multirow[b]{2}{*}{ Mat. } & \multicolumn{2}{|c|}{ Backing } & \multicolumn{2}{|c|}{ Deposit } & \multirow{2}{*}{$\begin{array}{c}\text { Deposit } \\
\text { Area } \\
\left(\mathrm{cm}^{2}\right)\end{array}$} & \multirow{2}{*}{$\begin{array}{l}\text { Frag. } \\
\text { Range } \\
\left(\mathrm{cm}^{2}\right)\end{array}$} & \multirow[b]{2}{*}{ Quality } \\
\hline & & $\begin{array}{l}\text { Dia. } \\
(\mathrm{cm})\end{array}$ & $\begin{array}{l}\text { Thick } \\
(\mathrm{cm})\end{array}$ & $\begin{array}{l}\text { Dia. } \\
\text { (crn) }\end{array}$ & Comp. & & & \\
\hline$U--2356-5$ & $\mathrm{Pt}$ & 5.08 & 0.0127 & 2.52 & $\mathrm{U}_{3} \mathrm{O}_{8}$ & 4.988 & 6.0 & G \\
\hline$U-2356-6$ & 11 & $" 1$ & & 2.54 & 110 & 5.067 & 11 & $\mathrm{G}$ \\
\hline$U-2356-7$ & $"$ & $"$ & $"$ & 2.52 & $" 1$ & 4.988 & $" 1$ & $\mathrm{G}$ \\
\hline $\mathrm{N}-\mathrm{U} 5-2$ & St & 1.905 & 0.254 & 1.27 & 11 & 1.267 & $"$ & $\mathrm{G}$ \\
\hline $\mathrm{N}-\mathrm{U} 5-3$ & 11 & & $"$ & "1" & 11 & 11 & $" 1$ & $\mathrm{~F}$ \\
\hline R5 & $" 1$ & 4.445 & 0.127 & 2.22 & $"$ & 3.761 & " & $\mathrm{G}$ \\
\hline $25 \mathrm{~S}-5--3$ & $\mathrm{Pt}$ & 1.905 & 0.0127 & 1.27 & $\mathrm{UO}_{2}$ & 1.267 & 6.6 & $\mathrm{G}$ \\
\hline$U-235-6$ & Mo & 6.985 & $"$ & 2.58 & $\mathrm{UO}_{4} \cdot \mathrm{H}_{2} \mathrm{O}$ & 5.228 & 4.1 & $\mathrm{~F}$ \\
\hline $\mathrm{U}-235-10$ & $" 1$ & & $"$ & 2.768 & " & 6.018 & $"$ & $\mathrm{G}$ \\
\hline$U-235-14$ & $" 1$ & 18 & $"$ & 2.758 & $"$ & 5.974 & $"$ & $\mathrm{~F}$ \\
\hline$U-235-1$ & St & $"$ & 0.0254 & 2.54 & $"$ & 5.067 & $"$ & $\mathrm{G}$ \\
\hline U-235-2 & " & $"$ & $"$ & 11 & $"$ & 11 & $"$ & $\mathrm{P}$ \\
\hline$U-235-3$ & 11 & $"$ & $" 1$ & 11 & $" 1$ & 11 & $" 1$ & $\mathrm{G}$ \\
\hline $\mathrm{U}-235-\mathrm{J}$ & $\mathrm{Pt}$ & $"$ & 0.0127 & 5.08 & $\mathrm{U}_{3} \mathrm{O}_{8}$ & 20.27 & 6.0 & - \\
\hline $\mathrm{U}-235-\mathrm{P}$ & $"$ & " & & $"$ & $" 1$ & $" 1$ & $"$ & - \\
\hline$U-235-S$ & $" 1$ & $" 1$ & $" 1$ & $"$ & $" 1$ & $" 1$ & $"$ & - \\
\hline $\mathrm{U}-235-\mathrm{T}$ & $"$ & $"$ & $"$ & $"$ & $"$ & $"$ & $"$ & - \\
\hline$U-236-1$ & St & 6.985 & 0.0254 & - & $\mathrm{UO}_{4} \cdot \mathrm{H}_{2} \mathrm{O}$ & - & 4.1 & - \\
\hline$U-236-2$ & $"$ & $" 1$ & $"$ & 2.580 & & 5.228 & $"$ & - \\
\hline$U-236-3$ & $"$ & $" 1$ & $"$ & 2.580 & $" 1$ & $"$ & $"$ & - \\
\hline$U-236-4$ & $" 1$ & $"$ & $"$ & 2.510 & $"$ & 4.948 & $" 1$ & - \\
\hline $\mathrm{U}-236-5$ & $"$ & $" 1$ & $"$ & 2.540 & $"$ & 5.067 & $"$ & - \\
\hline$U-236-6$ & $" 1$ & 11 & $"$ & 2.620 & $"$ & 5.391 & $" 1$ & - \\
\hline $\mathrm{U}-236-34$ & Mo & 11 & 0.0127 & 2.540 & $" 1$ & 5.067 & $" 1$ & - \\
\hline $\mathrm{U}-236-35$ & $"$ & $"$ & $"$ & $" 1$ & $" 1$ & 11 & $" 1$ & - \\
\hline$U-236-36$ & $"$ & $"$ & $"$ & 2.520 & $"$ & 4.988 & $"$ & - \\
\hline$U-236-46$ & $"$ & $"$ & $"$ & - & $"$ & - & $"$ & - \\
\hline$U-236-46$ & $"$ & $"$ & $" 1$ & - & 11 & - & $"$ & - \\
\hline$U-238-59$ & St & 6.985 & 0.0254 & 2.540 & $" 1$ & 5.067 & 4.1 & $\mathrm{~F}$ \\
\hline$U-238-60$ & 11 & & & & $" 1$ & & $" 1$ & $\mathrm{G}$ \\
\hline$U-238-210$ & $\mathrm{Pt}$ & 5.08 & 0.0127 & 2.54 & $\mathrm{U}_{3} \mathrm{O}_{8}$ & $"$ & 6.0 & G \\
\hline$U-238-211$ & $"$ & & & & & $"$ & 11 & $\mathrm{P}$ \\
\hline $\mathrm{U}-238-212$ & $"$ & $"$ & $"$ & $"$ & $"$ & $" 1$ & $" 1$ & - \\
\hline$U-238-213$ & $"$ & $" 1$ & 11 & $"$ & 11 & $"$ & "1 & $\mathrm{P}$ \\
\hline$U-238-214$ & $"$ & " & $"$ & $"$ & $"$ & $"$ & $"$ & 一 \\
\hline$U-238-217$ & $"$ & " & $"$ & $"$ & $"$ & " & $"$ & - \\
\hline $\begin{array}{l}U-238-4 \\
U-238-11\end{array}$ & Mo $_{11}$ & ${ }_{11}^{6.985}$ & 0.0127 & - & $\mathrm{UO}_{4} \cdot \mathrm{H}_{2} \mathrm{O}$ & - & 4.1 & - \\
\hline$U-238-13$ & 11 & $"$ & & 2.833 & $"$ & 6.326 & $"$ & - \\
\hline
\end{tabular}


Table II. (continued)

\begin{tabular}{|c|c|c|c|c|c|c|c|c|}
\hline \multirow[b]{2}{*}{$\begin{array}{c}\text { Sample } \\
\text { No. }\end{array}$} & \multirow[b]{2}{*}{ Mat. } & \multicolumn{2}{|c|}{ Backing } & \multicolumn{2}{|c|}{ Deposit } & \multirow{2}{*}{$\begin{array}{c}\text { Deposit } \\
\text { Area } \\
\left(\mathrm{cm}^{2}\right)\end{array}$} & \multirow{2}{*}{$\begin{array}{l}\text { Frag. } \\
\text { Range } \\
\left(\mathrm{cm}^{2}\right)\end{array}$} & \multirow{2}{*}{ Quälity } \\
\hline & & $\begin{array}{l}\text { Dia. } \\
(\mathrm{cm})\end{array}$ & $\begin{array}{l}\text { Thick } \\
\text { (cm) }\end{array}$ & $\begin{array}{l}\text { Dia. } \\
(\mathrm{cm})\end{array}$ & Comp. & & & \\
\hline $\begin{array}{l}U-238-15 \\
U-238-8\end{array}$ & Mo & 6.985 & 0.0127 & 二 & $\mathrm{UO}_{4} \cdot \mathrm{H}_{2} \mathrm{O}$ & - & 4.1 & G \\
\hline U-238-9 & $"$ & " & & $\overline{2.522}$ & " & 4.996 & 11. & $\bar{G}$ \\
\hline $\mathrm{U}-238-26$ & $\mathrm{Si}$ & $"$ & 0.0254 & 0.54 & $\mathrm{UF}_{4}$ & 5.067 & 4.7 & G \\
\hline $\mathrm{U}-238-\mathrm{K}$ & $\mathrm{Pt}$ & $"$ & 0.0127 & 5.08 & $\mathrm{U}_{3} \mathrm{O}_{8}$ & 20.27 & 6.0 & 一 \\
\hline $\mathrm{U}-238-\mathrm{L}$ & $"$ & $"$ & $"$ & $"$ & $"$ & $"$ & $"$ & - \\
\hline $\mathrm{U}-238-\mathrm{M}$ & " & $"$ & " & $"$ & $"$ & $"$ & $"$ & - \\
\hline $\mathrm{U}-238-\mathrm{O}$ & & $"$ & 0.0254 & - & $\mathrm{UO}_{4} \cdot \mathrm{H}_{2} \mathrm{O}$ & - & 4.1 & - \\
\hline 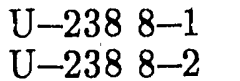 & $\mathrm{St}_{11}$ & $"$ & 11 & 二 & " & - & ".1 & E \\
\hline $\mathrm{U}-2388-3$ & $"$ & $"$ & $"$ & - & $"$ & - & " & - \\
\hline $\mathrm{Np}-237-56$ & $\mathrm{Pt}$ & 5.08 & 0.0127 & - & $\mathrm{NpO}_{2}$ & - & 5.6 & $\mathrm{~F}$ \\
\hline $\begin{array}{l}\mathrm{Np}-237-70 \\
\mathrm{Nn}-237-71\end{array}$ & $"$ & $"$ & $"$ & - & $"$ & - & $"$ & G \\
\hline $\begin{array}{l}\mathrm{Np}-237-71 \\
\mathrm{~Np}-237-72\end{array}$ & " & $"$ & $"$ & 二 & $"$ & E & $"$ & P \\
\hline $\begin{array}{l}\mathrm{Np}-237-72 \\
\mathrm{~Np}-237-73\end{array}$ & $"$ & $"$ & $"$ & 二 & $"$ & - & $"$ & $\mathrm{P}$ \\
\hline $\begin{array}{l}\mathrm{Np}-237-73 \\
\mathrm{~Np}-237-74\end{array}$ & " & $"$ & $"$ & - & " & - & " & $\mathrm{P}$ \\
\hline Np-237-75 & $"$ & $"$ & $"$ & - & $"$ & - & $"$ & $\mathrm{~F}$ \\
\hline $\mathrm{Np}-237-76$ & $"$ & $"$ & $"$ & 2.54 & $"$ & 5.067 & $"$ & G \\
\hline $\mathrm{Np}-237-77$ & $"$ & $"$ & $"$ & - & $"$ & - & $"$ & F \\
\hline $\mathrm{Np}-237-78$ & $"$ & $"$ & $"$ & - & $"$ & - & $"$ & $\mathrm{~F}$ \\
\hline $\mathrm{Np}-237-79$ & $"$ & $"$ & $"$ & 2.54 & $"$ & 5.067 & $"$ & G \\
\hline $\mathrm{Np}-237-89$ & $"$ & $"$ & $"$ & - & $"$ & - & & $\mathrm{P}$ \\
\hline $\mathrm{Pu}-239-12$ & $\mathrm{St}$ & 6.985 & 0.0254 & $\overline{0}$ & $\mathrm{PuO}_{2}$ & $\overline{4988}$ & 6.7 & $\begin{array}{l}\mathrm{F} \\
\mathrm{p}\end{array}$ \\
\hline $\mathrm{Pu}-239-13$ & $"$ & " & $"$ & 2.520 & $"$ & 4.988 & $"$ & $\begin{array}{l}\mathrm{P} \\
\mathrm{F}\end{array}$ \\
\hline $\begin{array}{l}\mathrm{Pu}-239-14 \\
\mathrm{Pu}-239-146\end{array}$ & $"$ & $"$ & $"$ & 2.500 & $"$ & 4.909 & $"$ & $\mathrm{~F}$ \\
\hline $\mathrm{Pu}-239-267$ & $"$ & $"$ & $"$ & ii & $"$ & 4.906 & $"$ & $\mathrm{P}$ \\
\hline $49 I-1-3$ & $\mathrm{Pt}$ & 1.905 & 0.0127 & 1.270 & $"$ & 1.267 & " & G \\
\hline$P u-242-49$ & Mo & 6.985 & 0.0127 & 2.500 & $"$ & 4.909 & 6.7 & $\mathrm{~F}$ \\
\hline
\end{tabular}


Table III-A. Thorium Isotopic Analysis in Mole \%.

\begin{tabular}{|c|c|c|c|}
\hline $\begin{array}{c}\text { Sample } \\
\text { No. }\end{array}$ & 230 & 232 & $\begin{array}{c}\text { Av. } \\
\text { Atomic } \\
\text { Wt. }\end{array}$ \\
\hline $\begin{array}{l}\text { Th-239-49 } \\
\text { Th-230-50 } \\
\text { Th-230-52 } \\
\text { Th-230-54 } \\
\text { Th-230-59 }\end{array}$ & $\begin{array}{c}99.600(0.60) \\
" 1 " \\
" 1 " \\
"\end{array}$ & $\begin{array}{c}0.400 \\
" 1 \\
" 1 \\
" 1 \\
" 1\end{array}$ & $\begin{array}{c}230.043 \\
" 1 \\
" 1 \\
" 1\end{array}$ \\
\hline $\begin{array}{l}\text { Th }-232-8 \\
\text { Th }-232-11 \\
\text { Th }-232-12 \\
\text { Th }-232-16 \\
\text { Th-232=21 }\end{array}$ & \multicolumn{2}{|c|}{$\begin{array}{l}\text { Natural thorium spiked with } \\
-0.4 \% \text { Th- } 230 \text {. No isotopic } \\
\text { analysis on this batch. }\end{array}$} & \\
\hline $\begin{array}{l}\text { Th }-232-30 \\
\text { Th }-232-31 \\
\text { Th }-232-34\end{array}$ & $\begin{array}{l}0.383 \\
11 \\
11\end{array}$ & $\begin{array}{l}99.617 \\
" 1\end{array}$ & $\begin{array}{c}232.030 \\
\text { " }\end{array}$ \\
\hline $\begin{array}{l}\text { Th-232-57 } \\
\text { Th-232-58 } \\
\text { Th-232-62 } \\
\text { Th-232-63 }\end{array}$ & $\begin{array}{l}0.0 \\
11 \\
11 \\
11\end{array}$ & $\begin{array}{c}100.0 \mathrm{Nat} \\
" 1 \\
" 1\end{array}$ & \\
\hline $\begin{array}{l}\text { Th-232-60 } \\
\text { Th }-232-61\end{array}$ & \multicolumn{3}{|c|}{ Natural thorium $+\sim 1 / 4 \%$ U--235 } \\
\hline
\end{tabular}


Table III-B. Isotopic Analysis in Mole \%.

\begin{tabular}{|c|c|c|c|c|c|c|c|}
\hline $\begin{array}{c}\text { Sample } \\
\text { No. }\end{array}$ & $\begin{array}{c}232 \\
\mathrm{ppm}\end{array}$ & 233 & 234 & 235 & 236 & 238 & $\begin{array}{c}\text { Av. } \\
\text { Atomic } \\
\text { Wt. }\end{array}$ \\
\hline $\begin{array}{l}U-233-1002 \\
U-233-1202 \\
U-233-1402 \\
U-233-10 \\
U-233-11 \\
U-233-12\end{array}$ & $\begin{array}{l}0.8 \\
11 \\
11 \\
11 \\
11\end{array}$ & $\begin{array}{c}99.540 \\
11 \\
11 \\
11 \\
11 \\
11\end{array}$ & $\begin{array}{l}0.184 \\
" 11 \\
" 1 \\
" 1 \\
" 1\end{array}$ & $\begin{array}{c}0.062 \\
11 \\
11 \\
11 \\
11 \\
11\end{array}$ & $\begin{array}{c}0.013 \\
11 \\
11 \\
11 \\
11 \\
11\end{array}$ & $\begin{array}{l}0.203 \\
" 1 \\
" 1 \\
" 1 \\
" 1\end{array}$ & $\begin{array}{c}233.058 \\
" 1 \\
11 \\
" 1 \\
11 \\
11\end{array}$ \\
\hline $\begin{array}{l}U--234-1 \\
U-234=3 \\
U-234-4 \\
U-234-5 \\
U-234-6 \\
U-234-31 \\
U-234-32 \\
U-234-48\end{array}$ & $\begin{array}{l}E \\
E \\
E\end{array}$ & $\begin{array}{l}E \\
\bar{z} \\
\bar{z} \\
0.005\end{array}$ & $\begin{array}{c}99.900 \\
" \\
" \\
" 1 \\
" \\
89.950 \\
" 1 \\
99.07\end{array}$ & $\begin{array}{c}0.064 \\
" 1 \\
" 1 \\
" 1 \\
" \\
9.920 \\
" 1 \\
0.08\end{array}$ & $\begin{array}{c}0.036 \\
" 1 \\
11 \\
" 1 \\
" \\
0.053 \\
1 " \\
0.055\end{array}$ & $\begin{array}{c}<0.007 \\
" 1 \\
" 1 \\
" 1 \\
" 1 \\
0.075 \\
" 1 \\
0.789\end{array}$ & $\begin{array}{c}234.045 \\
" 1 " \\
" 1 \\
" 1 \\
234.137 \\
" 1 \\
234.072\end{array}$ \\
\hline $\begin{array}{l}\mathrm{U}-235 \text { SST-1 } \\
\mathrm{U}-235 \text { SST-5 } \\
\mathrm{U}-235 \text { SST-8 }\end{array}$ & - & - & $\begin{array}{c}0.852 \\
11 \\
11\end{array}$ & $\begin{array}{c}93.283 \\
" 1 "\end{array}$ & $\begin{array}{c}0.328 \\
" 1 \\
" 1\end{array}$ & $\begin{array}{c}5.535 \\
11 \\
11\end{array}$ & $\begin{array}{c}235.200 \\
" 1\end{array}$ \\
\hline 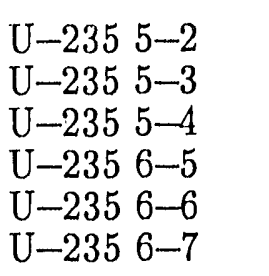 & E & E & $\begin{array}{c}1.0247 \\
" 1 " \\
" 1 \\
" 1 \\
"\end{array}$ & $\begin{array}{c}98.4897 \\
" 1 " \\
" 1 \\
" 1 \\
" 1 "\end{array}$ & $\begin{array}{c}0.4374 \\
1 " \\
11 \\
" 1 \\
" 1 \\
" 1\end{array}$ & $\begin{array}{c}0.0983 \\
" 1 \\
11 \\
" 1 \\
" 1 \\
" 1\end{array}$ & $\begin{array}{c}235.041 \\
11 \\
11 \\
11 \\
11 \\
11\end{array}$ \\
\hline $\begin{array}{l}\mathrm{N}-\mathrm{U} 5-2 \\
\mathrm{~N}-\mathrm{U} 5-3 \\
\mathrm{R} 5\end{array}$ & - & - & $\begin{array}{c}1.025 \\
11 \\
11\end{array}$ & $\begin{array}{c}98.440 \\
" 1 \\
" 1\end{array}$ & $\begin{array}{c}0.437 \\
11 \\
11\end{array}$ & $\begin{array}{c}0.098 \\
" 11 \\
11\end{array}$ & $\begin{array}{c}235.041 \\
\text { " }\end{array}$ \\
\hline $\begin{array}{l}U-235-1 \\
U-235-2 \\
U-235=3\end{array}$ & - & - & $\begin{array}{c}0.028 \\
" 1 " \\
" 1\end{array}$ & $\begin{array}{c}99.856 \\
\| \\
11\end{array}$ & $\begin{array}{c}0.062 \\
" 1 "\end{array}$ & $\begin{array}{c}0.056 \\
11 \\
11\end{array}$ & $\begin{array}{c}235.051 \\
\text { " } \\
" 1\end{array}$ \\
\hline $25 S-5-3$ & - & - & 0.0610 & 99.748 & 0.0652 & 0.1261 & 235.048 \\
\hline $\begin{array}{l}U-235-6 \\
U-235-10 \\
U-235-14\end{array}$ & - & $\begin{array}{c}5.127 \\
" 11\end{array}$ & $\begin{array}{c}0.050 \\
" 1\end{array}$ & $\begin{array}{c}94.420 \\
\text { "1 } \\
11\end{array}$ & $\begin{array}{l}0.307 \\
11 \\
11\end{array}$ & $\begin{array}{c}0.094 \\
11 \\
11\end{array}$ & $\begin{array}{c}234.942 \\
\text { " }\end{array}$ \\
\hline
\end{tabular}


Table III-B. (continued)

\begin{tabular}{lccccccc}
\hline $\begin{array}{c}\text { Sample } \\
\text { No. }\end{array}$ & 232 & 233 & 234 & 235 & 236 & 238 & $\begin{array}{c}\text { Av. } \\
\text { Atomic } \\
\text { Wt. }\end{array}$ \\
\hline
\end{tabular}

U-235-J

$\mathrm{U}-235-\mathrm{P}$

U-235-S

$\mathrm{U}-235-\mathrm{T}$

$\mathrm{U}-236-1$

$\mathrm{U}-236-2$

$\mathrm{U}-236-3$

$\mathrm{U}-236-4$

$\mathrm{U}-236-5$

U-236-6

U-236-34

U-236-35

U-236-36

U-236-46

U-236-47

$\mathrm{U}-238-59$

U-238-60

U-238-210

$\mathrm{U}-238-211$

U-238-212

$\mathrm{U}-238-213$

U-238-214

U-238-217

$\mathrm{U}-238-4$

U-238-11

$\mathrm{U}-238-13$

$\mathrm{U}-238-15$

$\mathrm{U}-238-8$

$\mathrm{U}-238-9$

U-238-26
These are deposits of

$-93 \%$ U-235 and

$-5 \%$ U-238. However,

exact analysis is not known.

\begin{tabular}{|c|c|c|c|c|c|}
\hline- & - & $0 . \Delta 02$ & 99.593 & 0.011 & 236.056 \\
\hline - & - & $"$ & 11 & 11 & 11 \\
\hline & & $"$ & 11 & 11 & 11 \\
\hline & & 11 & 11 & 11 & 11 \\
\hline & & 11 & 11 & 11 & 11 \\
\hline & - & $\|$ & 11 & 11 & 11 \\
\hline
\end{tabular}

No analysis

\begin{tabular}{|c|c|c|c|c|c|}
\hline- & 0.015 & 13.64 & 86.19 & 0.16 & 235.604 \\
\hline - & $\underset{11}{0.004}$ & 11.00 & ${ }_{\|}^{88.84}$ & 0.16 & 235.948 \\
\hline & $"$ & $"$ & $"$ & 11 & 11 \\
\hline$t$ & \multicolumn{2}{|c|}{$-<6$ ppm } & $\longrightarrow$ & 100.0 & 238.051 \\
\hline- & 1.0100 & 2.364 & 0.135 & 96.491 & 237.936 \\
\hline & 11 & 11 & 11 & 11 & $"$ \\
\hline & 11 & 11 & 11 & 11 & 11 \\
\hline & 11 & 11 & 11 & 11 & 11 \\
\hline & 11 & 11 & 11 & 11 & 11 \\
\hline
\end{tabular}

\begin{tabular}{|c|c|c|c|c|c|}
\hline 3.1 .53 & - & 0.01464 & - & 96.832 & 237.892 \\
\hline 11 & & 11 & ( & 11 & 11 \\
\hline "1 & & " & - & 11 & $"$ \\
\hline 6.091 & - & 0.0125 & - & 93.897 & 237.7 \\
\hline 10.050 & 0.022 & 0.015 & - & 89.914 & 237.5 \\
\hline- & & 0.415 & - & 99.585 & 238.0 \\
\hline
\end{tabular}


Table III-B. (continued)

\begin{tabular}{|c|c|c|c|c|c|c|c|}
\hline $\begin{array}{c}\text { Sample } \\
\text { No. }\end{array}$ & $\begin{array}{c}232 \\
\text { ppm }\end{array}$ & 233 & 234 & 235 & 236 & 238 & $\begin{array}{c}\text { Av. } \\
\text { Atomic } \\
\text { Wt. }\end{array}$ \\
\hline $\begin{array}{l}\mathrm{U}-238-\mathrm{K} \\
\mathrm{U}-238-\mathrm{L} \\
\mathrm{U}-238-\mathrm{M} \\
\mathrm{U}-238-\mathrm{O}\end{array}$ & $\begin{array}{l}-\mathrm{Na} \\
\text { val } \\
\text { ind }\end{array}$ & $\begin{array}{l}\text { al ure } \\
\text { give } \\
\text { enden }\end{array}$ & $\begin{array}{l}0.0055 \\
\text { n. Hanc } \\
\text { here is } \\
\text { alysis. }\end{array}$ & 0.72 & - & 99.2745 & 238.029 \\
\hline $\begin{array}{l}\mathrm{U}-238-8-1 \\
\mathrm{U}-238 \text { 8-2 } \\
\mathrm{U}-2388-3\end{array}$ & - & - & $\begin{array}{c}0.114 \\
" 1\end{array}$ & $\begin{array}{c}10.842 \\
" 1 "\end{array}$ & $\begin{array}{c}0.050 \\
11 \\
11\end{array}$ & $\begin{array}{c}88.993 \\
11\end{array}$ & $\begin{array}{c}237.716 \\
\text { " }\end{array}$ \\
\hline
\end{tabular}


Table III-C. Isotopic analysis for the neptunium and plutonium samples

\begin{tabular}{|c|c|c|c|c|c|c|c|}
\hline $\begin{array}{l}\text { Sample } \\
\text { No. }\end{array}$ & 237 & 238 & 239 & 240 & 241 & 242 & $\begin{array}{l}\text { Av. } \\
\text { Atomic } \\
\text { Wt. }\end{array}$ \\
\hline $\begin{array}{l}\mathrm{Np}-237-56 \\
\mathrm{~Np}-237-71 \\
\mathrm{~Np}-237-72 \\
\mathrm{~Np}-237-73 \\
\mathrm{~Np}-237-74 \\
\mathrm{~Np}-237-75 \\
\mathrm{~Np}-237-76 \\
\mathrm{~Np}-237-77 \\
\mathrm{~Np}-237-78 \\
\mathrm{~Np}-237-79 \\
\mathrm{~Np}-237-80\end{array}$ & $\begin{array}{c}100.0 \\
11 \\
11 \\
11 \\
11 \\
11 \\
11 \\
11 \\
11 \\
11\end{array}$ & $\begin{array}{l}E \\
E \\
E \\
E \\
-\end{array}$ & $\begin{array}{l}E \\
I \\
I \\
I\end{array}$ & $\begin{array}{l}- \\
E \\
z \\
E \\
E \\
-\end{array}$ & $\begin{array}{l}E \\
E \\
E \\
E \\
-\end{array}$ & $\begin{array}{l}E \\
z \\
z \\
z \\
z \\
-\end{array}$ & $\begin{array}{c}237.048 \\
" 1 " \\
" 1 \\
" 1 \\
" 1 \\
" 1 \\
" 1 \\
" 1 \\
11\end{array}$ \\
\hline $\begin{array}{l}\mathrm{Pu}-239-12 \\
\mathrm{Pu}-239-13 \\
\mathrm{Pu}-239-14\end{array}$ & - & - & $\begin{array}{c}98.944 \\
" 1 \\
"\end{array}$ & $\begin{array}{c}1.012 \\
" 11\end{array}$ & $\begin{array}{c}0.049 \\
" 11 \\
" 1\end{array}$ & E & $\begin{array}{c}239.077 \\
" 1 "\end{array}$ \\
\hline $\begin{array}{l}\mathrm{Pu}-239-146 \\
\mathrm{Pu}-239-267\end{array}$ & - & - & $\underset{\text { " }}{99.952}$ & 0.048 & - & - & 239.056 \\
\hline $49 I--1-3$ & - & - & 99.105 & 0.879 & 0.010 & 0.006 & 239.064 \\
\hline $\mathrm{Pu}-242-49$ & - & 0.007 & 9.128 & 0.097 & 0.099 & 90.669 & 241.054 \\
\hline
\end{tabular}


Table IV. Fission Sample Activities and Weights

\begin{tabular}{|c|c|c|c|c|c|c|c|}
\hline $\begin{array}{l}\text { Sample } \\
\text { No. }\end{array}$ & $\begin{array}{l}\text { Alpha } \\
\alpha / s\end{array}$ & $\begin{array}{c}\text { Activity } \\
\text { Random } \\
\text { Error } \\
\%\end{array}$ & $\begin{array}{l}\text { Specific Ao } \\
\mathrm{d} / \mathrm{s} / \text { atom }^{\mathrm{a}}\end{array}$ & $\begin{array}{l}\text { tivity } \\
\mathrm{d} / \mathrm{s} / \mu \mathrm{gg}\end{array}$ & $\begin{array}{c}\text { Atoms } \\
\text { Elementa }\end{array}$ & $\begin{array}{l}\text { Element } \\
(\mu \mathrm{g})\end{array}$ & $\begin{array}{c}\text { Wt. } \\
\mu \mathrm{g} / \mathrm{cm}^{2} \\
\text { Element }\end{array}$ \\
\hline $\begin{array}{l}\text { Th-230-49 } \\
\text { Th }-230-50 \\
\text { Th }-230-52 \\
\text { Th-230-54 } \\
\text { Th-230-59 }\end{array}$ & $\begin{array}{c}147852 \\
182992 \\
34054 \\
583446 \\
282892\end{array}$ & $\begin{array}{l}0.22 \\
0.19 \\
0.37 \\
0.06 \\
0.10\end{array}$ & $\begin{array}{c}2.8998(-13) \\
" 1 " \\
11 \\
" 1\end{array}$ & $\begin{array}{c}758.0 \\
11 \\
11 \\
11 \\
" 1\end{array}$ & $\begin{array}{c}0.5099(18) \\
0.6310(18) \\
0.1174(18) \\
2.012(18) \\
0.9756(18)\end{array}$ & $\begin{array}{r}195.1 \\
211.4 \\
44.9 \\
769.7 \\
373.2\end{array}$ & $\begin{array}{c}38.5 \\
47.6 \\
8.86 j \\
151.9 \\
73.6\end{array}$ \\
\hline $\begin{array}{l}\text { Th-232-8 } \\
\text { Th-232-11 } \\
\text { Th-232-12 } \\
\text { Th-232-16 } \\
\text { Th }-232-21 \\
\text { Th }-232-30 \\
\text { Th }-232-31 \\
\text { Th-232-34 } \\
\text { Th }-232-57 \\
\text { Th-232-58 } \\
\text { Th-232-62 } \\
\text { Th-232-63 } \\
\text { Th }-232-60 \\
\text { Th-232-61 }\end{array}$ & $\begin{array}{l}1334.7 \\
5894.2 \\
1972.9 \\
2314.3 \\
23524 . \\
4063.1 \\
4080.6 \\
8489.2 \\
- \\
- \\
-\end{array}$ & $\begin{array}{l}0.33 \\
0.14 \\
0.28 \\
0.24 \\
0.20 \\
0.17 \\
0.16 \\
0.11 \\
= \\
= \\
=\end{array}$ & $\begin{array}{c}\bar{z} \\
\bar{z} \\
1.1176(-15) \\
" 1 \\
= \\
= \\
=\end{array}$ & $\begin{array}{l}= \\
\bar{Z} \\
\bar{Z} \\
2.901 \\
11 \\
\bar{E} \\
\bar{E} \\
=\end{array}$ & $\begin{array}{c}= \\
= \\
\bar{z} \\
3.636(18) \\
3.651(18 \\
7.596(18) \\
= \\
= \\
=\end{array}$ & $\begin{array}{l}\overline{-} \\
\overline{-} \\
\overline{1} \\
1401 \\
2926 \\
\overline{-} \\
\bar{Z} \\
\bar{E}\end{array}$ & $\begin{array}{l}E \\
- \\
\overline{-} \\
276.5 \\
277.7 \\
577.4 \\
- \\
- \\
- \\
-\end{array}$ \\
\hline $\begin{array}{l}U-233-1002 \\
U-233-1202 \\
U-233-1402 \\
U-233-10 \\
U-233-11 \\
U-233-12\end{array}$ & $\begin{array}{r}77538 \\
90836 \\
106138 \\
- \\
-\end{array}$ & $\begin{array}{l}0.10 \\
0.10 \\
0.10 \\
- \\
-\end{array}$ & $\begin{array}{c}1.3750(-13) \\
" 1 \\
" \\
- \\
-\end{array}$ & $\begin{array}{c}355.3 \\
11 \\
11 \\
- \\
-\end{array}$ & $\begin{array}{c}0.5639(18) \\
0.6606(18) \\
0.7719(18) \\
- \\
-\end{array}$ & $\begin{array}{l}218.2 \\
255.7 \\
298.7 \\
- \\
-\end{array}$ & $\begin{array}{l}44.1 \\
51.3 \\
61.8 \\
- \\
-\end{array}$ \\
\hline $\begin{array}{l}U-234-1 \\
U-234-3 \\
U-234-4 \\
U-234-5 \\
U-234-6 \\
U-234-31 \\
U-234-32 \\
U-234-48\end{array}$ & $\begin{array}{l}\overline{68457} \\
82220 \\
96356 \\
\overline{39093} \\
75057 \\
\end{array}$ & $\begin{array}{l}\overline{0.13} \\
0.12 \\
0.07 \\
\overline{0.12} \\
0.05 \\
-\end{array}$ & $\begin{array}{c}8.9309(-14) \\
" \\
" 1 \\
" \\
8.0418(-14) \\
" 1 " \\
8.8592(-14)\end{array}$ & $\begin{array}{c}229.8 \\
" 1 \\
" 1 \\
" 1 \\
206.9 \\
" 1 \\
228.0\end{array}$ & $\begin{array}{c}\overline{0} \\
0.7665(18) \\
0.9204(18) \\
1.079(18) \\
0.4861(18) \\
0.9333(18) \\
\end{array}$ & $\begin{array}{l}\overline{297.9} \\
357.7 \\
407.1 \\
\overline{189.0} \\
362.8 \\
-\end{array}$ & $\begin{array}{l}\overline{58.8} \\
72.3 \\
85.6 \\
- \\
38.5 \\
73.9 \\
\end{array}$ \\
\hline $\begin{array}{l}U-235 \text { SST }-1 \\
U-235 \text { SST }-5 \\
U-235 \text { SST }-8\end{array}$ & $\begin{array}{c}1358.4 \\
846.8 \\
2062.3\end{array}$ & $\begin{array}{l}\overline{0.20} \\
0.15\end{array}$ & $\begin{array}{c}7.9414(-16) \\
" 1\end{array}$ & $\begin{array}{c}2.034 \\
1 " \\
" 1\end{array}$ & $\begin{array}{l}1.710(18) \\
1.066(18 \\
2.597(18)\end{array}$ & $\begin{array}{l}657.8 \\
416.3 \\
1014 .\end{array}$ & $\begin{array}{c}131.8 \\
82.2 \\
200.1\end{array}$ \\
\hline
\end{tabular}


Table IV. (continued)

\begin{tabular}{|c|c|c|c|c|c|c|c|}
\hline $\begin{array}{l}\text { Sample } \\
\text { No. }\end{array}$ & $\begin{array}{l}\text { Alpha } \\
\alpha / \mathrm{s}\end{array}$ & $\begin{array}{l}\text { Activity } \\
\text { Randorn } \\
\text { Error } \\
\%\end{array}$ & $\begin{array}{l}\text { Specific Ac } \\
\text { d/s/atom }{ }^{a}\end{array}$ & $\begin{array}{l}\text { ctivity } \\
\mathrm{d} / \mathrm{s} / \mu \mathrm{g}\end{array}$ & $\begin{array}{c}\text { Atnms } \\
\text { Elementa }\end{array}$ & $\begin{array}{c}\text { Element } \\
(\mu \mathrm{g})\end{array}$ & $\begin{array}{l}\text { Wt. } \\
\mu \mathrm{g} / \mathrm{cm}^{2} \\
\text { Elerrent }\end{array}$ \\
\hline $\begin{array}{l}U-2355-2 \\
U-2355-3 \\
U-2355-4 \\
U-2356-5 \\
U-2356--6 \\
U-2356-7 \\
N-U 5-2 \\
N-U 5-3 \\
R .5 \\
25 S-5-3 \\
U-235-6 \\
U-235-10 \\
U--235-14 \\
U-235-1 \\
U-235-2 \\
U-235-3 \\
U-235-J \\
U-235-P \\
U-235-S \\
U-235-T\end{array}$ & $\begin{array}{c}2029.3 \\
789.86 \\
886.6 \\
3446.8 \\
2034.3 \\
2901.5 \\
\overline{127.2} \\
194.1 \\
50.82 \\
5283.6 \\
4918.3 \\
6601.6 \\
= \\
- \\
- \\
-\end{array}$ & $\begin{array}{l}0.10 \\
0.13 \\
0.12 \\
0.10 \\
0.11 \\
0.11 \\
\overline{(0.3)} \\
0.3 \\
0.3) \\
0.10 \\
0.14 \\
0.07 \\
- \\
- \\
- \\
- \\
-\end{array}$ & $\begin{array}{c}9.5090(-16) \\
" 1 " \\
" 1 \\
" 1 \\
" 1 \\
" 1 \\
" 1 \\
8.6250(-17) \\
7.1921(-15) \\
" 1 " \\
- \\
- \\
-\end{array}$ & $\begin{array}{c}2.436 \\
" 1 \\
" 1 \\
" 1 \\
" 1 \\
" 1 \\
" 1 \\
" \\
0.2210 \\
18.44 \\
1 " \\
= \\
= \\
= \\
=\end{array}$ & $\begin{array}{c}2.134(18) \\
0.8306(18) \\
0.9324(18) \\
3.625(18) \\
3.191(18) \\
3.051(18) \\
\overline{-} \\
0.1338(18) \\
0.2041(18) \\
0.5892(18) \\
0.7346(18) \\
0.6838(18) \\
0.9179(18) \\
- \\
(1.005(18))^{\mathrm{b}} \\
- \\
-\end{array}$ & $\begin{array}{c}833.0 \\
324.2 \\
364.0 \\
1415 . \\
1240 . \\
1191 . \\
\overline{52.2} \\
79.6 \\
230.0 \\
286.5 \\
266.7 \\
358.0 \\
- \\
- \\
(10400) \mathrm{c} \\
(9700) \mathrm{c} \\
(10200) \mathrm{c} \\
(11700) \mathrm{c}\end{array}$ & $\begin{array}{r}172.4 \\
64.0 \\
71 \hat{u} \\
283.7 \\
245.7 \\
238.8 \\
\overline{41.2} \\
20.6 \\
181.5 \\
54.8 \\
44.3 \\
59.9 \\
- \\
- \\
(513) \\
478 \\
498 \\
577)\end{array}$ \\
\hline $\begin{array}{l}U-236-1 \\
U-236-2 \\
U-236-3 \\
U-236-4 \\
U-236-5 \\
U-236-6 \\
U-236-34 \\
U-236-35 \\
U-236-36 \\
U-236-46 \\
U-236-47\end{array}$ & $\begin{array}{c}- \\
679.4 \\
1503.8 \\
919.9 \\
1418.0 \\
1591.1 \\
1061.2 \\
617.06 \\
1312.7 \\
-\end{array}$ & $\begin{array}{l}-\overline{0.45} \\
0.48 \\
0.28 \\
0.23 \\
0.25 \\
0.35 \\
0.25 \\
0.20 \\
-\end{array}$ & $\begin{array}{c}9.3418(-16) \\
" \\
" \\
" \\
" \\
" \\
8.2602(-16) \\
8.3664(-16) \\
" 1 \\
"\end{array}$ & $\begin{array}{c}2.38 \cdot 1 \\
" 1 \\
" 1 \\
" 1 \\
" 1 \\
" \\
2.112 \\
2.136 \\
-\end{array}$ & $\begin{array}{c}\overline{0} \\
0.7273(18) \\
1.610(18) \\
0.9847(18) \\
1.518(18) \\
1.703(18) \\
1.136(18) \\
0.7470(18) \\
1.569(18) \\
-\end{array}$ & $\begin{array}{l}\overline{285.0} \\
630.8 \\
385.9 \\
594.8 \\
667.4 \\
445.1 \\
292.2 \\
614.6 \\
-\end{array}$ & $\begin{array}{r}\overline{54.5} \\
120.7 \\
78.0 \\
117.4 \\
123.8 \\
87.8 \\
57.7 \\
123.2 \\
- \\
\end{array}$ \\
\hline $\begin{array}{l}U-238-59 \\
U-238-60 \\
U-238-210 \\
U-238-211 \\
U-238-212 \\
U-238-213 \\
U-238-214 \\
U-238-217\end{array}$ & $\begin{array}{c}33.58 \\
24.33 \\
2718.2 \\
3914.8 \\
3971.2 \\
1376.2 \\
537.2 \\
1011.9\end{array}$ & $\begin{array}{l}0.40 \\
0.32 \\
0.13 \\
0.12 \\
0.09 \\
0.09 \\
0.20 \\
0.20\end{array}$ & $\begin{array}{c}4.9169(-18) \\
\text { " } \\
9.1001(-16) \\
" 1 " \\
" \\
" \\
"\end{array}$ & $\begin{array}{c}0.01244 \\
" \\
2.304 \\
" 1 \\
" \\
" \\
" \\
"\end{array}$ & $\begin{array}{l}6.831(18) \\
4.949(18 \\
2.987(18 \\
4.302(18 \\
4.364(18) \\
1.512(18) \\
0.5903(18) \\
1.112(18)\end{array}$ & $\begin{array}{l}2699 . \\
1956 . \\
1180 . \\
1699 \\
1724 . \\
597.3 \\
233.2 \\
439.2\end{array}$ & $\begin{array}{r}532.6 \\
386.0 \\
232.9 \\
335.3 \\
34.0 \\
117.9 \\
46.0 \\
86.7\end{array}$ \\
\hline
\end{tabular}


Table IV. (continued)

\begin{tabular}{|c|c|c|c|c|c|c|c|}
\hline \multirow{2}{*}{$\begin{array}{l}\text { Sample } \\
\text { No. }\end{array}$} & \multicolumn{2}{|c|}{ Alpha Activity } & \multicolumn{2}{|c|}{ Specific Activity } & \multirow{2}{*}{$\begin{array}{c}\text { Atoms } \\
\text { Elementa }\end{array}$} & \multirow{2}{*}{$\begin{array}{l}\text { Element } \\
(\mu \mathrm{g})\end{array}$} & \multirow{2}{*}{$\begin{array}{c}\text { Wt. } \\
\mu \mathrm{g} / \mathrm{cm}^{2} \\
\text { Element }\end{array}$} \\
\hline & $\alpha / \mathrm{s}$ & $\underset{\%}{\text { Error }}$ & $d / s / a$ tom & $\mathrm{d} / \mathrm{s} / \mu \mathrm{g}$ & & & \\
\hline$U-238-4$ & - & - & $4.3550(-15)$ & 11.03 & - & - & - \\
\hline U-238-11 & - & - & $" 1$ & $"$ & - & - & $\cdots$ \\
\hline$U-238-13$ & - & - & $"$ & 11 & $\overline{1}$ & - & $\overline{-0}$ \\
\hline$U-238-15$ & 3965.9 & 0.11 & $" 1$ & $"$ & $0.9106(18)$ & 359.6 & 56.8 \\
\hline$U-238-8$ & - & - & $"$ & " & & - & - \\
\hline$U-233-9$ & 13508 & 0.14 & $1.3889(-14)$ & 35.22 & $0.9726(18)$ & 383.5 & 76.8 \\
\hline$U-238-26$ & - & - & & . & & $(950)$ & $(187)$ \\
\hline$U-233-K$ & - & - & $1.0022(-17)$ & 0.02536 & - & $(12000)^{c}$ & $(592)$ \\
\hline $\mathrm{U}-238-\mathrm{L}$ & - & - & & " & - & $(11100) \mathrm{c}$ & $(548)$ \\
\hline $\mathrm{U}-238-\mathrm{M}$ & - & - & $"$ & $"$ & - & $(7400) \mathrm{c}$ & $(365)$ \\
\hline$U-238-0$ & - & - & " & $"$ & - & $(13000) \mathrm{c}$ & $(64 i)$ \\
\hline $\mathrm{U}-2388-1$ & - & - & $1.1014(-16)$ & 0.2790 & - & - & $\ldots$ \\
\hline$U-2388-2$ & - & - & 11 & 11 & 一 & - & - \\
\hline$U-2388-3$ & - & - & $" 1$ & $" 1$ & - & - & - \\
\hline$N p-237-56$ & 1686.6 & 0.29 & $1.0264(-14)$ & 26.08 & $0.1643(18)$ & 64.7 & 12.8 \\
\hline iJp--237-70 & 1740.2 & 0.60 & $" 1$ & " & $0.1695(18)$ & 66.7 & 13.2 \\
\hline $\mathrm{Np}-237-71$ & 13469 & 0.18 & $"$ & $"$ & $1.312(18)$ & 516.4 & 101.9 \\
\hline$N_{p}-237-72$ & 6907.1 & 0.22 & " & $"$ & $0.6729(18)$ & 264.8 & 52.3 \\
\hline $\mathrm{Np}-237-73$ & 3846.0 & 0.40 & $"$ & 11 & $0.3747(18)$ & 147.5 & 29.1 \\
\hline$N p-237-74$ & 28970 & 0.20 & $"$ & $"$ & $2.822(18)$ & 1111. & 219.3 \\
\hline $\mathrm{Np}-237-75$ & 3752 & 0.13 & $"$ & $"$ & $3.656(18)$ & 1439. & 284.0 \\
\hline$N p-237-76$ & 4628 & 0.12 & $"$ & $"$ & $4,599(18)$ & 1775. & 350.3 \\
\hline$N p-237-77$ & 39038 & 0.35 & $" 1$ & $"$ & $3.803(18$ & 1497. & 295.4 \\
\hline$N p-237-78$ & 6786.2 & 0.28 & $"$ & " & $0.6612(18)$ & 260.2 & 51.4 \\
\hline $\mathrm{Np}-237-79$ & 17108 & 0.08 & $"$ & $"$ & $1.667(18)$ & 656.0 & 129.5 \\
\hline$N p-237-80$ & 1834 & 0.21 & $"$ & $"$ & $1.787(18)$ & 703.2 & 138.8 \\
\hline $\mathrm{Pu}-239-12$ & 469590 & 0.16 & $9.3529(-13)$ & 2356 & $0.5021(18)$ & 199.3 & - \\
\hline$P u-239-13$ & 662231 & 0.05 & & $"$ & $0.7080(18)$ & 281.1 & 56.4 \\
\hline $\mathrm{Pu}-239-14$ & 827860 & 0.04 & "1 & "1 & $0.8851(18)$ & 351.4 & - \\
\hline$P u-239-146$ & 1625146 & 0.04 & $9.1220(-13)$ & 2301 & $1.782(18)^{\prime}$ & 706.3 & 143.9 \\
\hline $\mathrm{Pu}-239-278$ & 298311 & 0.07 & & 11 & $0.3270(18)$ & 129.6 & 26.4 \\
\hline $49 I-1-3$ & 245700 & & $9.3230(-13)$ & 2349 & $0.2635(18)$ & 104.6 & 82.6 \\
\hline$P u-242-49$ & 76858 & 0.10 & $1.3973(-13)$ & 349.1 & $0.5500(18)$ & 220.2 & 44.9 \\
\hline
\end{tabular}

aNumber in parenthesis indicates power of 10 .

bNo. atoms based on comparison if fission rate with other samples.

cWeight determined by direct weighıs.g. 
Table V. Errors other than counting statistics and their sources in $\%$

\begin{tabular}{|c|c|c|c|c|c|c|c|c|}
\hline \multirow{2}{*}{$\begin{array}{l}\text { Sample } \\
\text { Nus. }\end{array}$} & \multirow{2}{*}{$t_{1 / 2}$} & \multirow{2}{*}{$\begin{array}{l}\text { Isotopic } \\
\text { Analysis }\end{array}$} & \multicolumn{3}{|c|}{ Sample Corr. Error } & \multicolumn{2}{|c|}{$\begin{array}{c}\text { Fully } \\
\text { Correlated }\end{array}$} & \multirow[t]{2}{*}{$\begin{array}{l}\text { Total } \\
\text { Corr. } \\
\text { Error }\end{array}$} \\
\hline & & & & & & Apparatus & Dist. & \\
\hline Th-230 (49-59) & 0.4 & $\mathrm{~N}$ & 0.05 & 0.06 & 0.1 & 0.10 & 0.03 & 0.43 \\
\hline Thi-232 $(30-34)$ & 0.4 & $0.4(230)$ & 0.10 & 0.10 & 0.25 & 11 & 0.06 & 0.64 \\
\hline$U-233(1002-12)$ & 0.13 & $N(233)$ & 0.05 & 0.06 & 0.1 & $"$ & 0.03 & 0.21 \\
\hline $0-234(1-6)$ & 0.12 & $N(234)$ & 0.05 & 0.06 & 0.1 & $" 1$ & 0.03 & 0.20 \\
\hline $11-2: 34(31-32)$ & 0.12 & $N(234)$ & 0.05 & 0.06 & 0.1 & $"$ & 0.03 & 0.20 \\
\hline$(1-2), 4-18$ & 0.12 & $N\{234\}$ & 0.05 & 0.06 & 0.1 & " & 0.03 & 0.20 \\
\hline $1-205\left(3612-1-591^{2}-8\right)$ & 0.12 & $0.43(234)$ & 0.10 & 0.10 & $\mathrm{~N}$ & " & 0.06 & 0.48 \\
\hline $11-235(5-2-[6)$ & 0.12 & $0.20(234)$ & 0.10 & 0.10 & 0.25 & " & 0.06 & 0.39 \\
\hline$U-23525 \mathrm{~S}-5-3$ & 0.16 & $0.4(234,235)$ & 0.22 & 0.10 & $\mathrm{~N}$ & is & 0.10 & 0.51 \\
\hline$U-235(0-14)$ & 0.13 & $0.2(233)$ & 0.10 & 0.10 & 0.25 & $"$ & 0.06 & 0.39 \\
\hline$U-235(1-3)$ & 0.10 & $10.0(234,235)$ & 0.22 & 0.22 & 0.44 & " & 0.10 & 10.02 \\
\hline $\mathrm{U}-235\left(\mathrm{~J}-\mathrm{T}^{\mathrm{T}}\right)$ & 0.12 & $-(234)$ & 0.10 & 0.20 & 0.82 & $"$ & 0.06 & - \\
\hline $\mathrm{U}-236(1-6)^{\prime}$ & 0.17 & $N(236)^{\prime}$ & 0.10 & 0.10 & 0.25 & $"$ & 0.10 & 0.36 \\
\hline$U-236-35$ & 0.17 & N (236) & 0.10 & 0.10 & 0.25 & $"$ & 0.10 & 0.36 \\
\hline$U-236(36-47)$ & 0.17 & $\mathrm{~N}(236)$ & 0.10 & 0.10 & 0.25 & $"$ & 0.10 & 0.36 \\
\hline U- -2383$\} 59-60^{\circ}$ & 0.11 & $N(238)$ & 0.22 & 0.22 & 0.44 & $"$ & 0.10 & 0.57 \\
\hline$U-238(211-217)$ & 0.12 & $0.4(234)$ & 0.10 & 0.10 & 0.25 & $"$ & 0.06 & 0.52 \\
\hline$U-238(4-15)$ & 0.13 & $0.20(233)$ & 0.10 & 0.10 & 0.25 & $"$ & 0.06 & 0.39 \\
\hline$U-238-\cdots 8$ & 0.13 & $0.10(233)$ & 0.10 & 0.10 & 0.25 & $"$ & 0.06 & 0.35 \\
\hline$U-238-9$ & 0.13 & $0.10(233)$ & 0.10 & 0.10 & 0.25 & $"$ & 0.06 & $0.3 j$ \\
\hline$U-238-26$ & 0.11 & $6.3(235)^{\prime}$ & 0.22 & 0.22 & $\mathrm{~N}$ & $"$ & 0.10 & 6.31 \\
\hline $\mathrm{J}-238(\mathrm{~K}-\mathrm{O})$ & 0.16 & $10.0(234,238)$ & 0.10 & 0.10 & 0.82 & $"$ & 0.10 & 10.04 \\
\hline$U-2.38(8-1-8-3)$ & 0.12 & $5.0(234)$ & 0.22 & 0.22 & 0.44 & $"$ & 0.10 & 5.03 \\
\hline$N_{1}--237(50-80)$ & 0.17 & $\mathrm{~N}(237)^{\circ}$ & 0.10 & 0.10 & 0.06 & $"$ & 0.06 & 0.51 \\
\hline$l^{\prime}(1-299)(12-14)$ & 0.12 & N $(239)$ & 0.06 & 0.06 & 0.06 & $"$ & 0.03 & 0.19 \\
\hline$l^{\prime}(1-230)(140-267)$ & 0.12 & $N(239)$ & 0.06 & 0.06 & 0.06 & $"$ & 0.03 & 0.19 \\
\hline$\left.P_{11-2}+2\right\} 9491-1-3$ & 0.12 & $N(239)$ & 0.06 & 0.06 & 0.06 & $"$ & 0.03 & 0.19 \\
\hline$l^{3} u-242-49$ & 0.32 & $\mathrm{~N}(239,242)$ & 0.06 & 0.06 & 0.06 & " & 0.03 & 0.35 \\
\hline
\end{tabular}




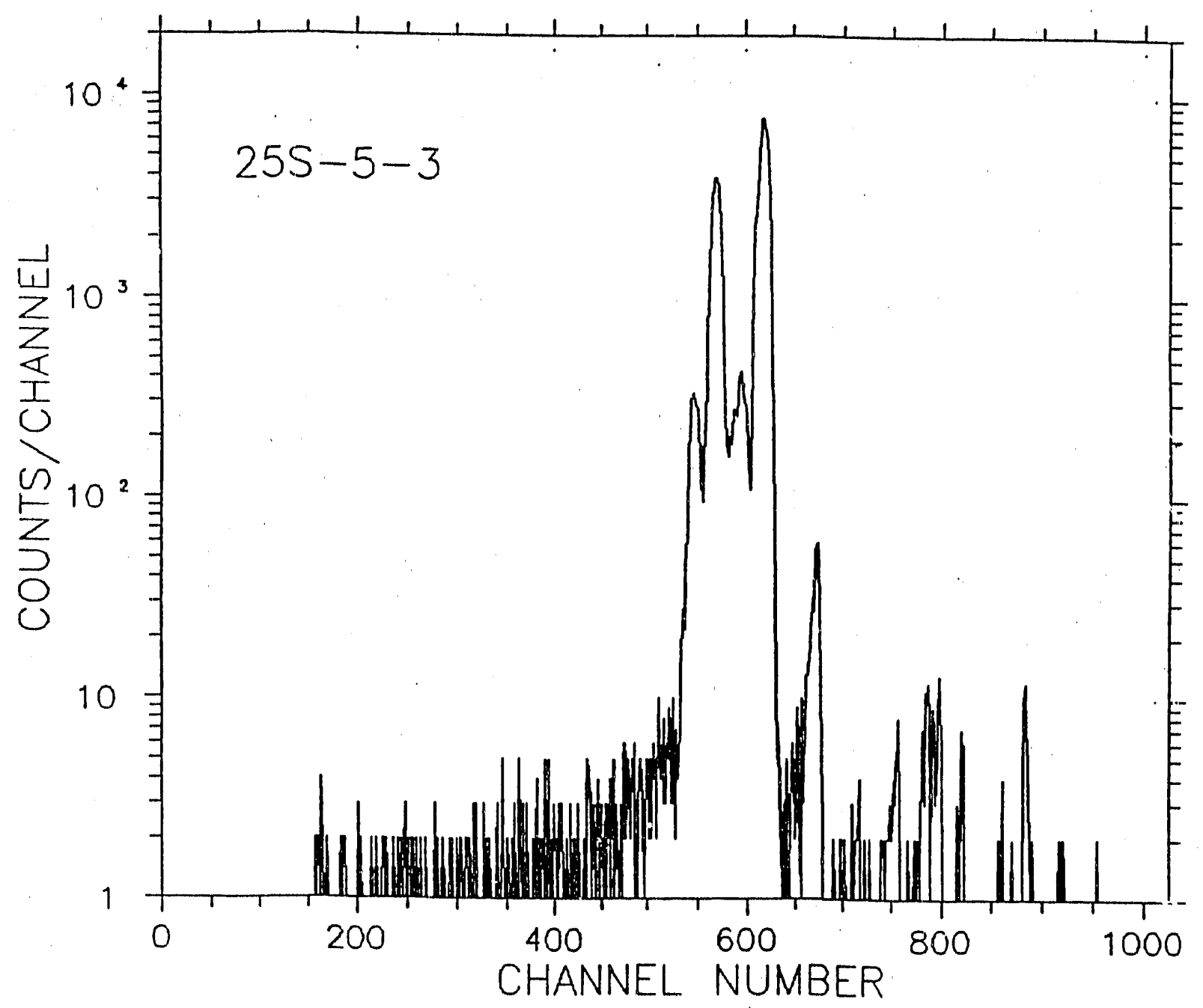

Fig. 1. The alpha spectrum of deposit 25S-5-3. The geometry factor is 213.3 and the live time is $614231 \mathrm{sec}$. 


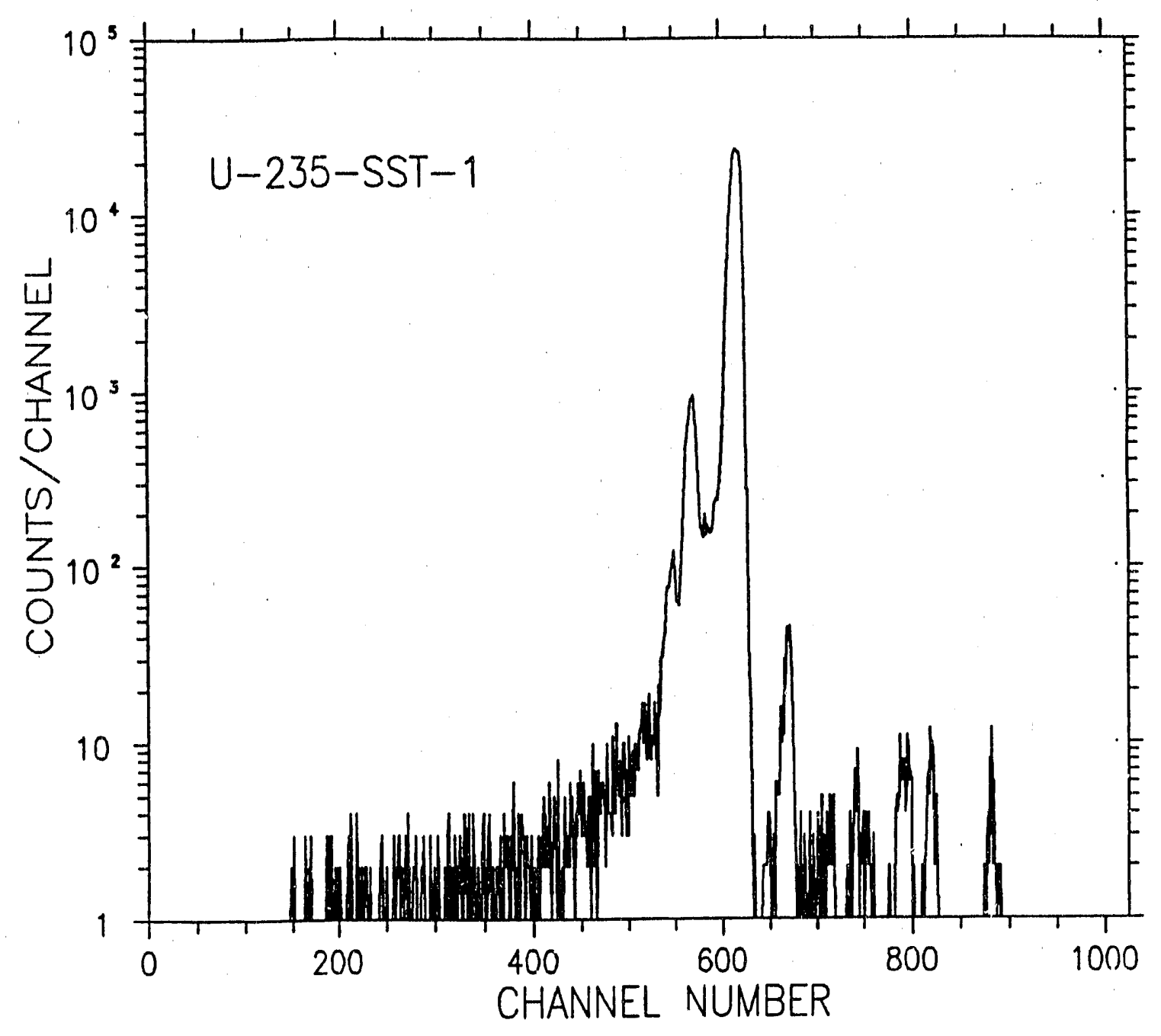

Fig. 2. The alpha spectrum of deposit U-235 SST-1. The geometry factor is 936.8 and the live time is $235090 \mathrm{sec}$. 


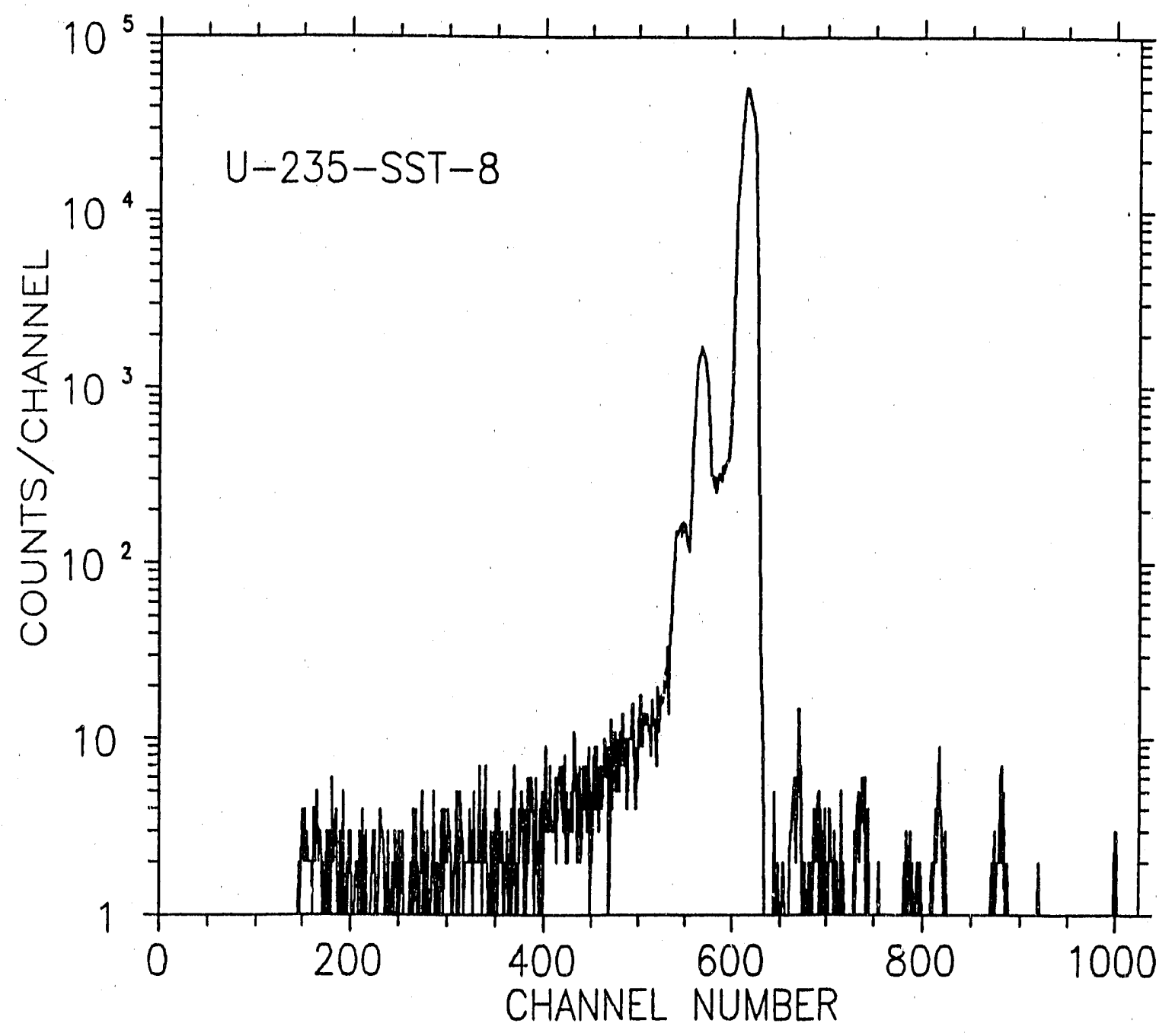

Fig. 3. The alpha spectrum of deposit U-235 SST-8. The geometry factor is 936.8 and the live time is $79349 \mathrm{sec}$. 


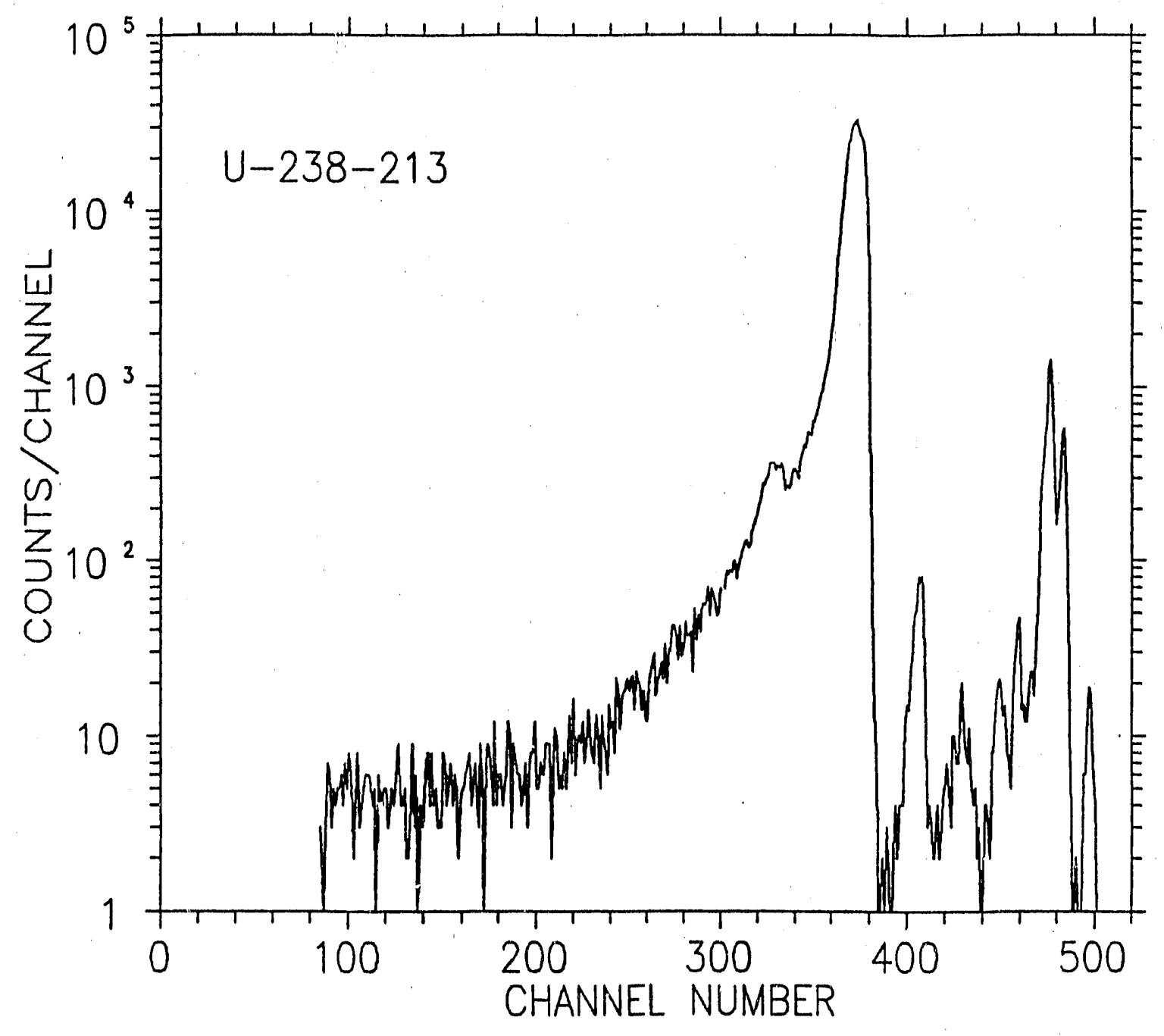

Fig. 4. The alpha spectrum of deposit U-238-213. The geometry factor is 938.9 and the live time is $241160 \mathrm{sec}$. 


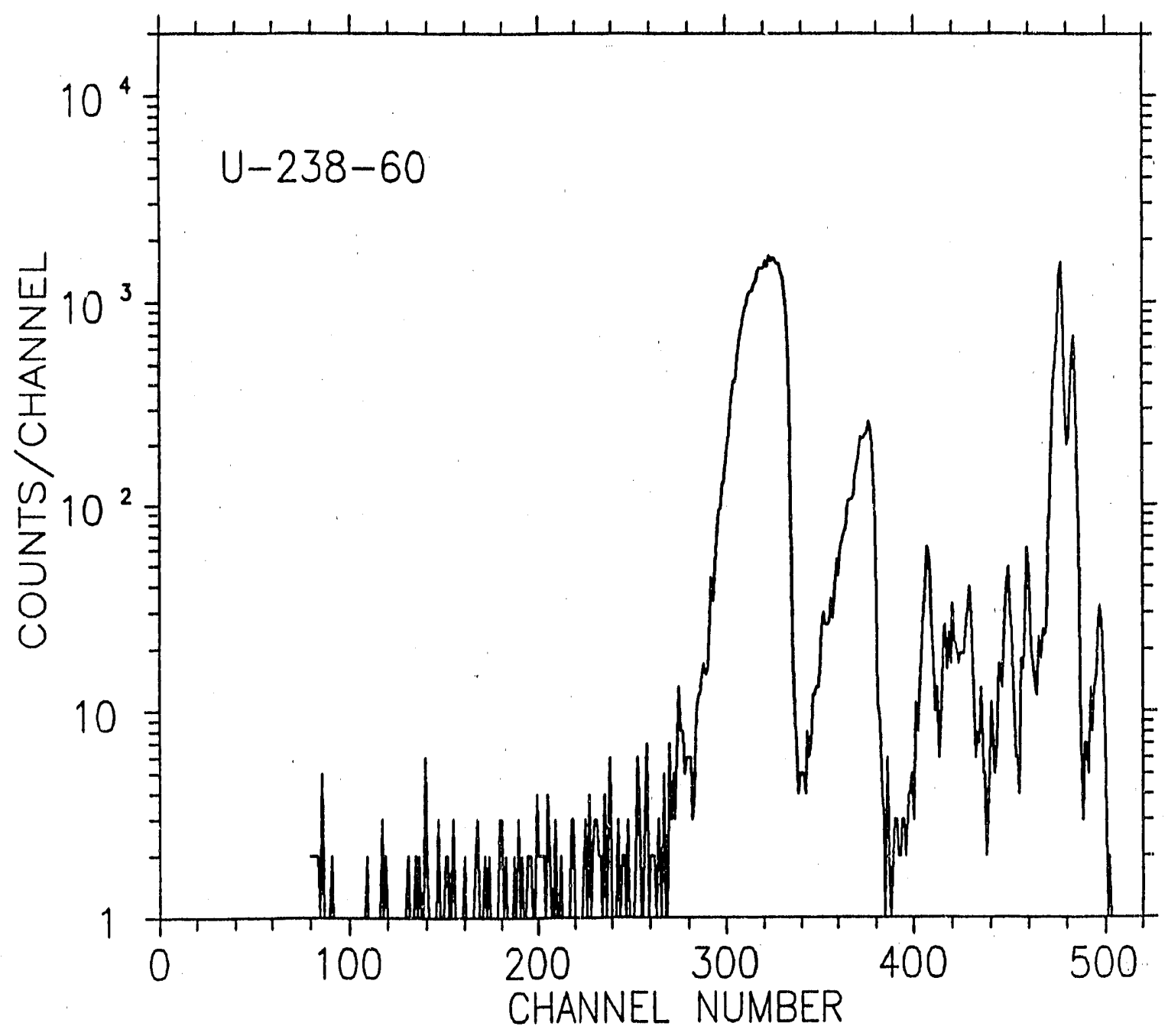

Fig. 5. The alpha spectrum of deposit U-238-60. The geometry factor is 221.0 and the live time is $329974 \mathrm{sec}$. 


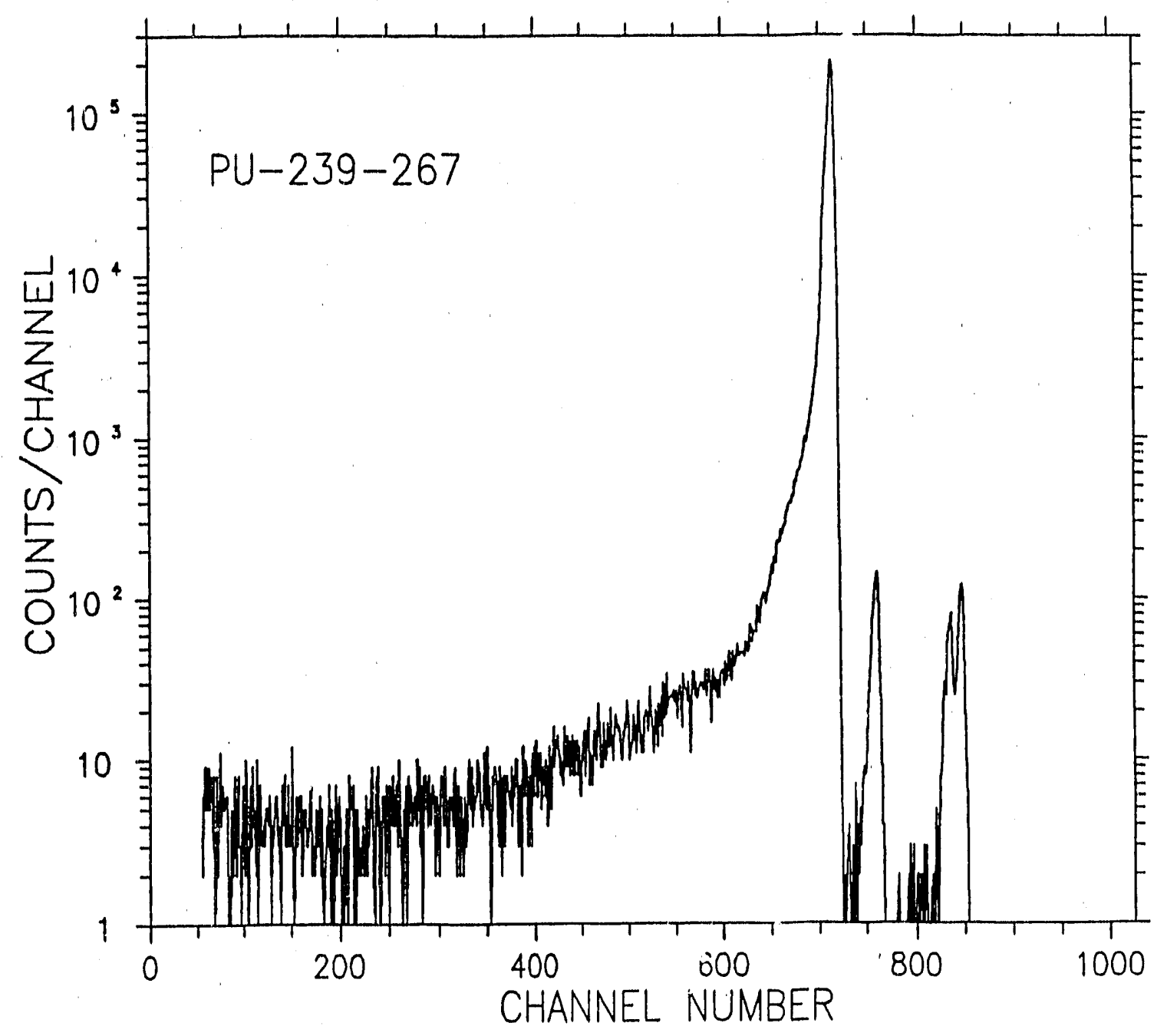

Fig. 6. The alpha spectrum of deposit $\mathrm{Pu}-239-267$. The geometry factor is 2164 and the live time is $11089 \mathrm{sec}$. 


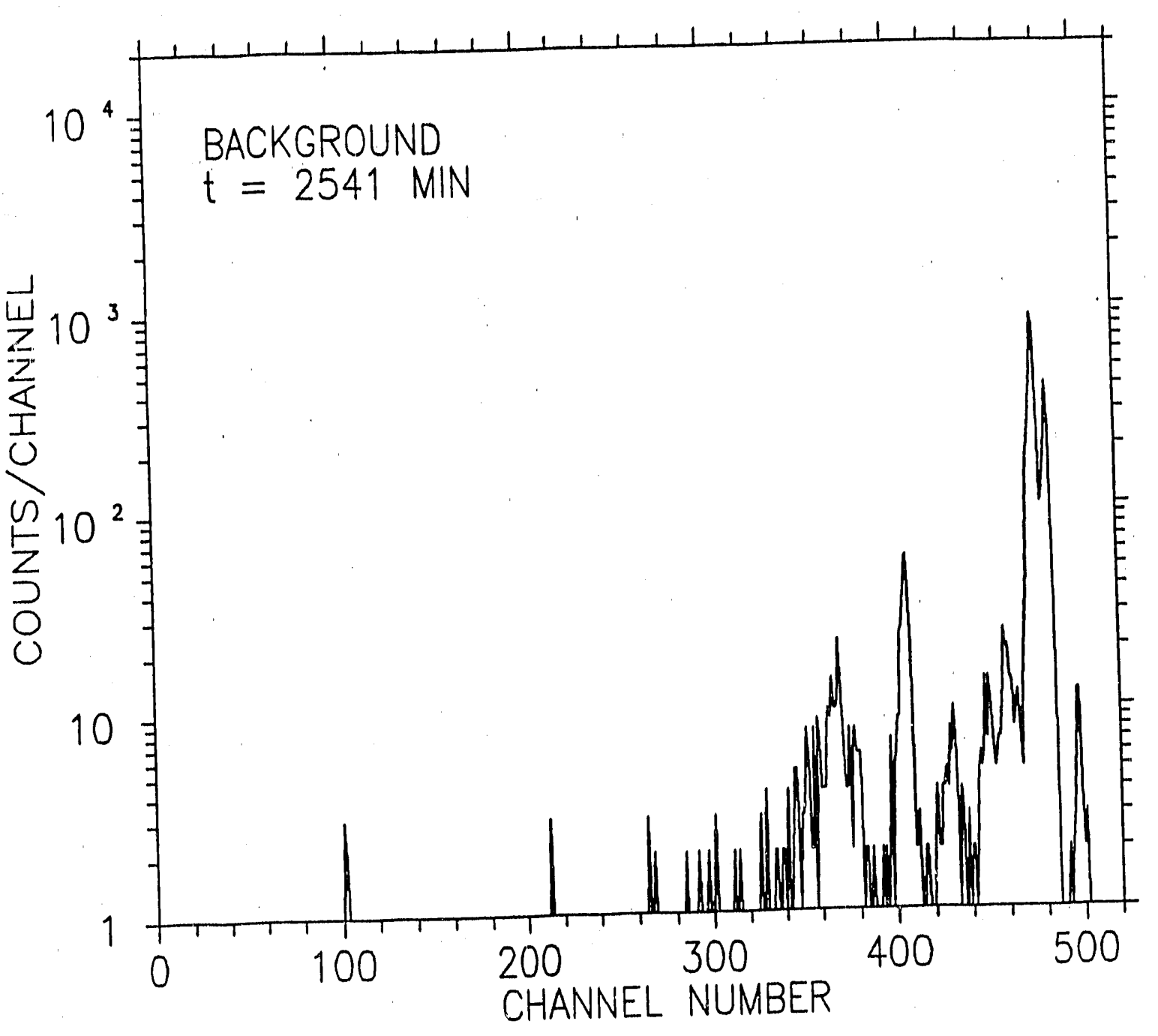

Fig. 7. A typical background spectrum. The live time is $152460 \mathrm{sec}$. 


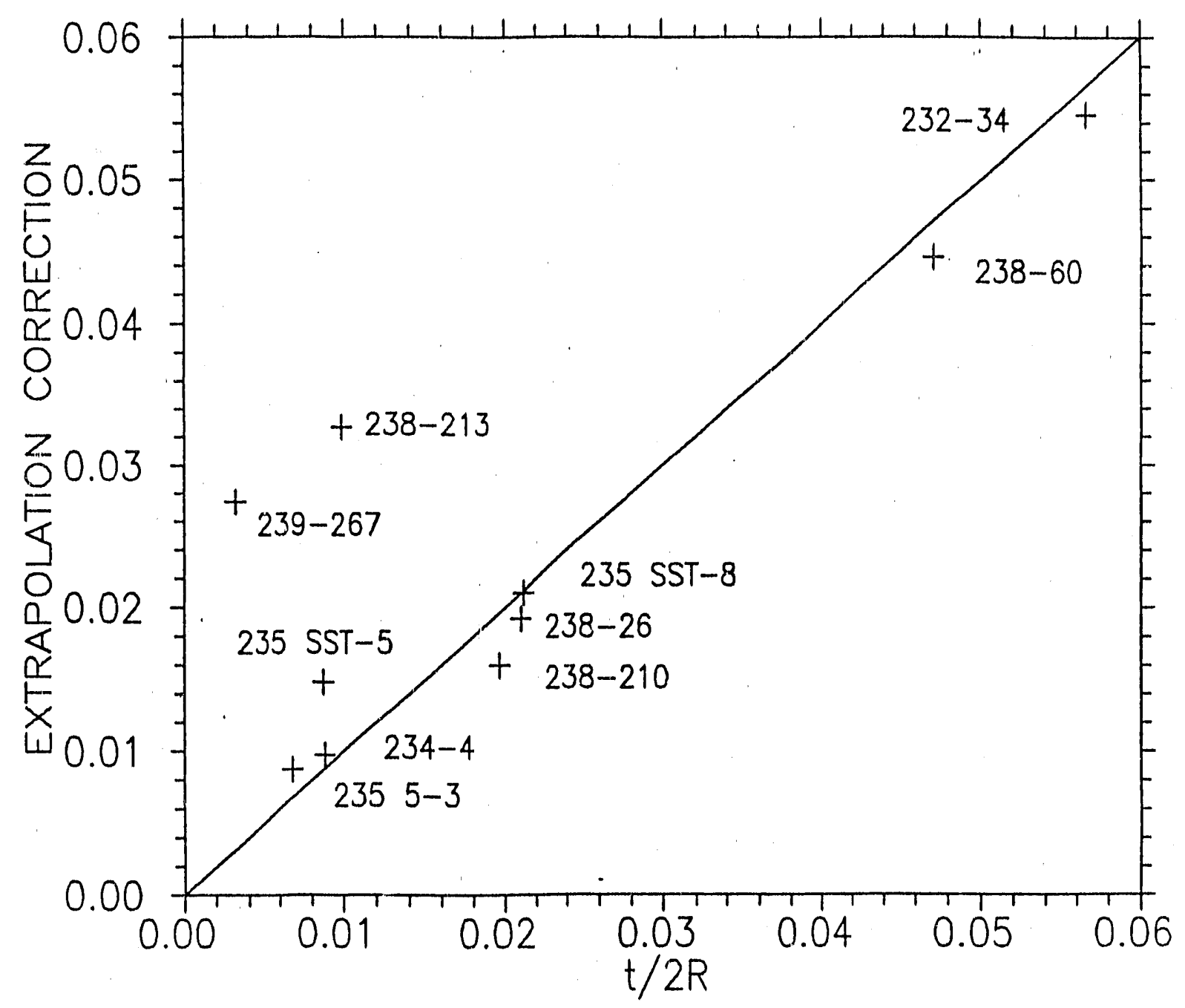

Fig. 8. The correlation of the fission spectrum extrapolation correction with the $t / 2 R$, the fraction of the fission lost in the deposit. 

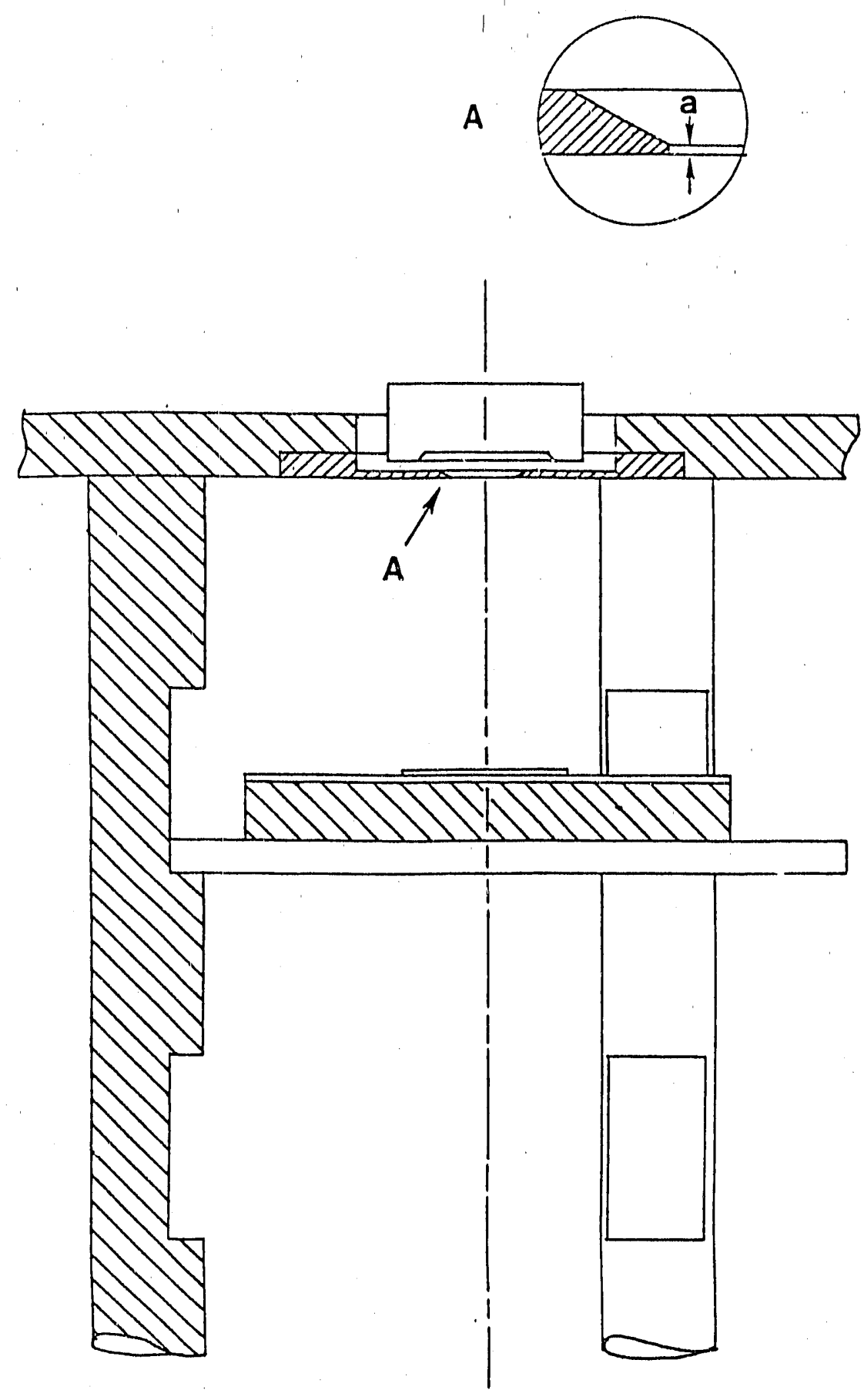

Fig. 9. A simplified diagram of the interior of the low geometry alpha counter. The vacuum chamber and the lower four counting positions are not shown. The drawing is approximately to scale, but the deposit thickness and the dimension " $a$ " have been exaggerated. 

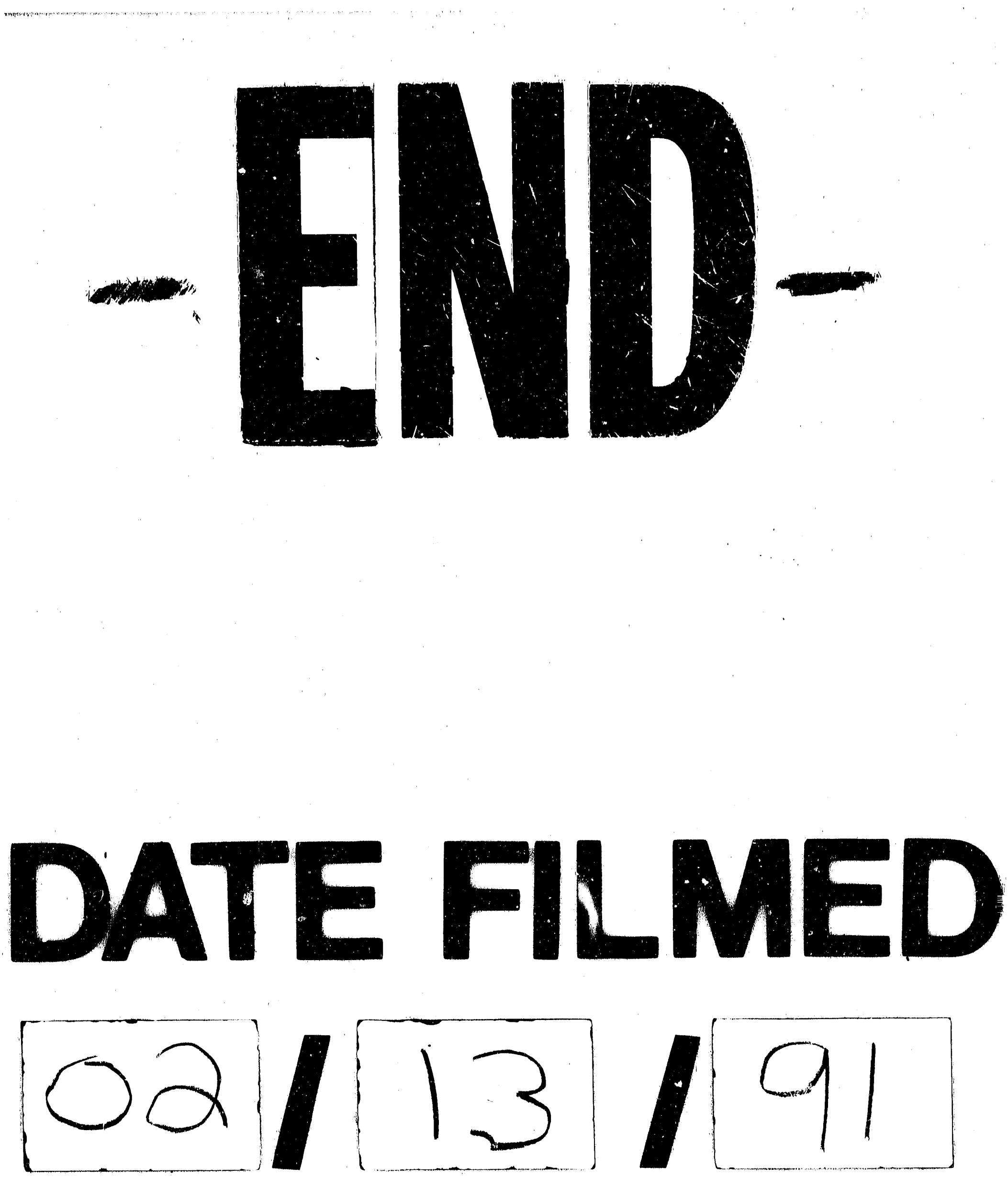